\title{
Petrochemistry and tectonic setting of Lower Cretaceous tholeiites from Franz Josef Land, U.S.S.R.
}

\author{
JOHN C. BAILEY AND C. KENT BROOKS
}

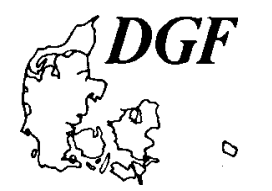

\begin{abstract}
Bailey, J. C. and Brooks, C. K.: Petrochemistry and tectonic setting of Lower Cretaceous tholeiites from Franz Josef Land, U.S.S.R. Bull. Geol. Soc. Denmark, vol. 37, pp. 31-49, Copenhagen, October 14th, 1988. https://doi.org/10.37570/bgsd-1988-37-04

The whole-rock geochemistry and mineral chemistry of six samples of Lower Cretaceous tholeiitic basalt from Franz Josef Land, U.S.S.R., have been studied. Geochemical criteria indicate that the basalts are initial rifting tholeiites characterised by low contents of $\mathrm{Ti}$ and other $\mathrm{H}$-elements, suggesting derivation from a depleted mantle source. These tholeiites formed during a Lower Cretaceous rifting stage in the formation of the Arctic Ocean basin, most likely the opening of the Canada Basin.
\end{abstract}

J. C. Bailey \& C. K. Brooks, Institute for Petrology, Øster Voldgade 10, Copenhagen, DK-1350, Denmark, November 3rd, 1987.

\section{Introduction}

Franz Josef Land is an arctic archipelago lying east of Svalbard and north of Novaya Zemlya (fig. 1). It has been claimed that the archipelago was discovered by a Norwegian sealer from Hammerfest in 1865 , though the relevant log-books were apparently destroyed by fire (Horn 1930). Credit for the first sighting, on August 30 1873, is usually given to an Austro-Hungarian expedition led by Julius Payer. This was followed by a Dutch sighting in 1879 and by the explorations of the English steam yachtsman, B. L. Smith, in 1880 and 1881-2.

In 1894, Alfred Harmsworth, an English newspaper proprietor, fitted out an expedition led by Frederick G. Jackson. It was planned to undertake a thorough exploration with scientific observations of Franz Josef Land, and to journey northwards to the pole. Jackson established winter quarters near Cape Flora, at the western end of Northbrook Island (fig. 2). Sledge and boat journeys in 1895-1897 yielded considerable geological information as well as materials which were later carefully described (Newton \& Teall 1897, 1898; Koettlitz 1898; Jackson 1899). In the summer of 1896 Jackson unexpectedly met Fridtjof Nansen; he had travelled south from his ship, the "Fram", whose soundings had established great depths in the Arctic basin, north of Franz Josef Land. Jackson's achievements earned him in 1898 a knighthood first class of the Danish Royal Order of St. Olaf. Some of the rocks collected by the Jackson-Harmsworth expedition were eventually stored in the British Museum of Natural History and were kindly made available for the present studies.

This communication is stimulated by the current economic interest in the Barents Shelf, discussion on the tectonic evolution of the Arctic ocean floor, and the complete lack of modern petrologic studies on Franz Josef Land.

\section{Tectonic setting}

Franz Josef Land is located at the northern edge of the Barents continental shelf. At the present day, this shelf is tilted gently southwards so that Franz Josef Land is located, like Svalbard, on the shallow, uptilted northern rim of the shelf. The deep seismic sounding methods employed by $\mathrm{Be}-$ liayevsky (1968) suggested that the continental crust beneath the Barents Sea, after removal of unconsolidated sediments, is about $25 \mathrm{~km}$ thick but there is a distinct thickening at $80^{\circ} \mathrm{N}$ to roughly $40 \mathrm{~km}$ thick, i.e. at the latitude of Franz Josef Land. 


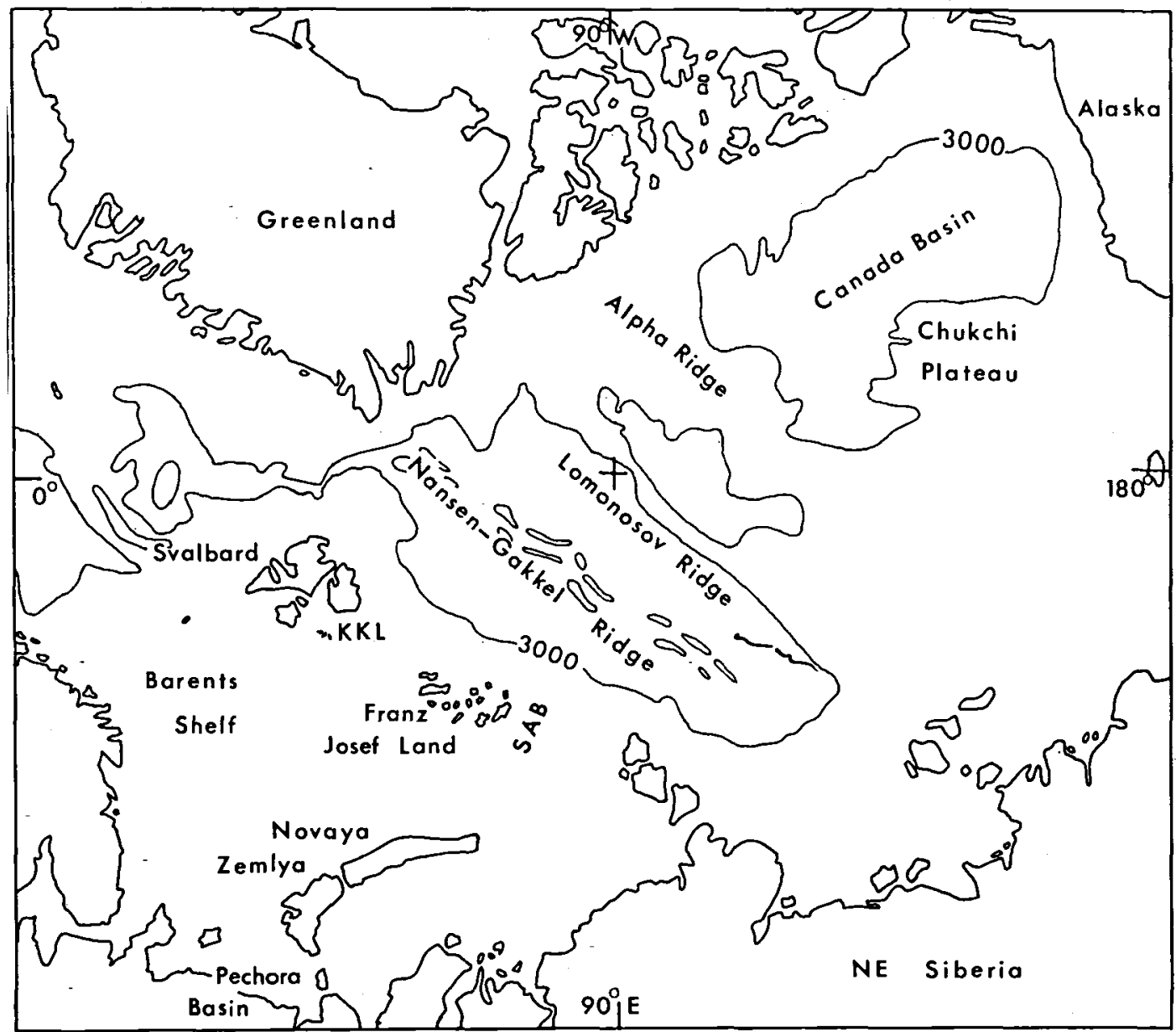

Fig. 1 Location map for Franz Josef Land showing main geological features of the Arctic Ocean basin. KKL Kong Karls Land, SAB St. Anna's Basin.

The Barents Shelf has been a stable epicontinental platform since at least the Late Palaeozoic (Gabrielson et al. 1984). Platform conditions persisted throughout the Mesozoic and extended from Svalbard in the west through Kong Karls Land and Franz Josef Land to the Arctic Urals, the lower Yenisei and the islands of the Kara Sea (Nalivkin 1973). There was a broad northerly uplift of the Barents platform area inferred from sediment transport patterns and basinal closure to the north (Steel \& Worsley 1984; Dibner et al. 1962). A major magmatic event appears to coincide with this northerly uplift: the eruption and intrusion of large volumes of tholeiitic magmas in late Jurassic and early Cretaceous times in Svalbard, Kong Karls Land and Franz Josef Land.
This event appears to be uprepresented elsewhere in the Soviet Western Artic (Nalivkin 1973) and is thus confined to the northern rim of the Barents Shelf. Similarly, a major Upper Cretaceous transgression which advanced from the south into the southern parts of the Soviet Western Artic is absent on Franz Josef Land and Svalbard. These areas probably underwent major uplift at this time. On Svalbard, it can be shown that there was subsequent southerly tilting and erosion over the whole of the archipelago.

A large embayment in the edge of the Barents Shelf is located immediately east of Franz Josef Land. This is St. Anna's Basin (fig. 1) which appears to extend southwestwards parallel to the western coast of Novaya Zemlya. Preliminary 


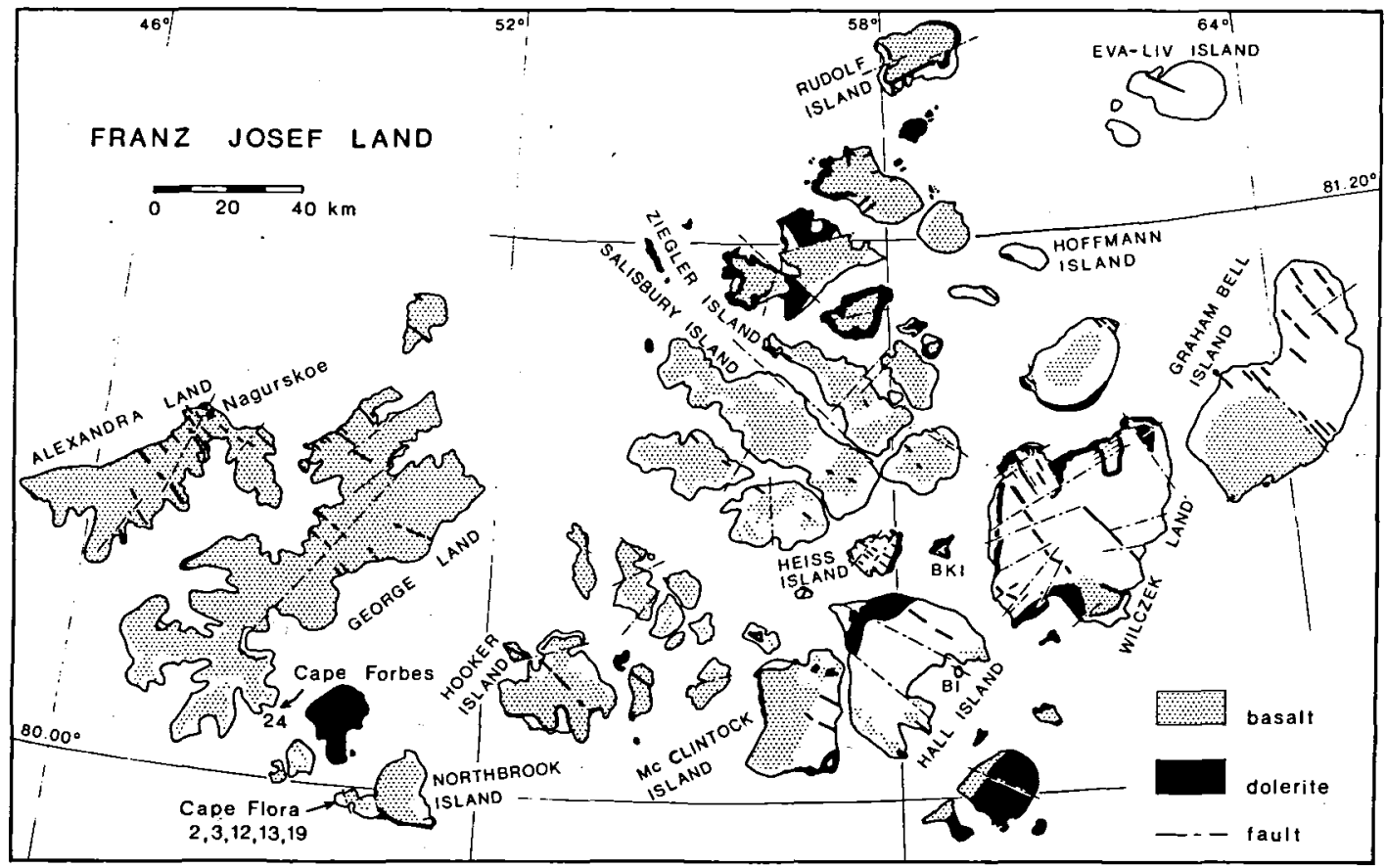

Fig. 2 Geological map of Franz Josef Land, based on Dibner (1970). Sediments are shown without pattern. BKI Bolshoy Komsomolskii Island, BI Berghaus Island. Sample localities are numbered.

seismic investigations (Vogt \& Ostenso 1973; Neprochnov et al. 1984) suggest the structure is a sedimentary basin, and a tectonic map presented by Steel \& Worsley $(1984$, fig. 37$)$ shows it joining southwards with the important Pechora Basin, located on the SE shores of the Barents Sea. We have been tempted to consider this basin as the failed arm of a triple function, the other two arms being part of the Nansen-Gakkel Ridge, or an older Artic spreading ridge. By analogy with the Kangerdlugssuaq area of East Greenland, such a triple function may be associated with enhanced magmatism (Brooks 1973; Burke \& Dewey 1973). In agreement with this suggestion, Gakkel et al. (1968) present a map showing a large basalt plateau extending $\mathrm{E}, \mathrm{SE}$ and $\mathrm{S}$ from Franz Josef Land to the edge of St. Anna's Basin.

After assessing geochemical evidence for the tectonic setting of the Lower Cretaceous tholeiites from Franz Josef Land, we place our interpretation in the broader context of recent plate tectonic models for the development of the Arctic Ocean basin.

\section{Previous investigations}

\section{Stratigraphy}

A list of geology publications dealing with Franz Josef Land prior to 1930 was given by Horn (1930). The most reliable geological descriptions of Franz Josef Land are found in recent Soviet publications (Dibner 1957, 1979; Dibner \& Krylova 1964; Tarakhovskiy et al. 1982, 1983) (fig. 2).

In a hole drilled at Nagurskoe in western Franz Josef Land, early Cretaceous basalts $(0-283 \mathrm{~m})$ overlie a Meso-Palaeozoic platform sedimentary cover (283-1895 m) and an upper Proterozoic folded, metamorphic basement (1895-3205 m) (Tarakhovskiy et al. 1982, 1983). Starting at a depth of $1230 \mathrm{~m}$, the platform sediments and folded basement have been cut by 21 intrusions ranging from basalt to gabbro. Using the $\mathrm{K}-\mathrm{Ar}$ dating technique, these intrusions gave ages from 203-94 myBP with a pronounced maximum around $121 \pm 18$ myBP (Lower Cretaceous).

The exposed sequence on Franz Josef Land consists of Upper Triassic and Jurassic strata with 


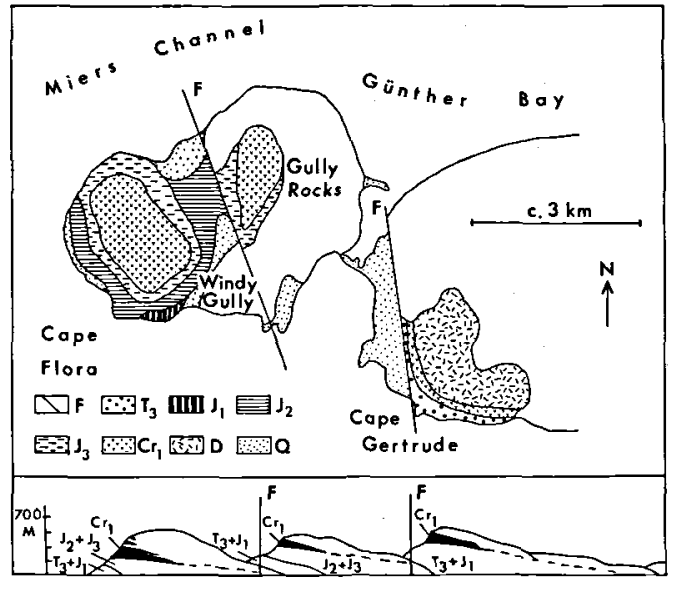

Fig. 3 Geological map and schematic section of Cape Flora, Northbrook Island, based on Dibner (1970). Ice is shown without pattern. F fault, T3 Upper Triassic, J1 Lower Jurassic, J2 Middle Jurassic, J3 Upper Jurassic, Cr1 Lower Cretaceous basalts, $\mathrm{D}$ dolerite sill, $\mathrm{Q}$ Quaternary.

an overall gentle dip to the NW which have been preserved beneath an unconformable capping of Lower Cretaceous basalts. The approximately $1500 \mathrm{~m}$ accumulation of Mesozoic sediments and igneous materials was compensated by the steady sinking of the region.

An extended summary of Soviet stratigraphic studies on Franz Josef Land was presented by Churkin et al. (1981) and only the briefest notes need be given here. The oldest exposed rocks are shale and coal beds of Carboniferous age. Above these are Upper Triassic marine limestone and shale, and Upper Triassic - Lower Jurassic continental sandstone, siltstone and argillite. The Middle and Upper Jurassic consist of shale, siltstone and sandy limestone. Unconformably above these lie Lower Cretaceous dolerite sills and basalt flows, separated by sandstone and carbonaceous shale with lenses of coal. The intervening sediments contain fossils indicating a Hauterivian to Albian age, i.e. about 124-100 myBP, similar to the maximum for $\mathrm{K}$-Ar age determinations.

\section{Magmatic rocks}

Since Soviet investigations on the magmatic rocks of Franz Josef Land have not been surveyed, to our knowledge, in the Western literature, we here present a review of the available studies. The basic sills and dikes which were recovered from the Nagurskoe drill hole have been divided petrographically into quartzose dolerites and gabbro-dolerites, taxitic gabbro-dolerites, and leucogabbro-dolerites occurring within layered intrusions with more that $60 \%$ plagioclase in their upper levels. All these varieties contain the same mineralogy - plagioclase, clinopyroxene, olivine, ore minerals, quartz and mesostasis - but with appreciable modal variations. At depths of 2120 $2690 \mathrm{~m}$, the intrusions have suffered intense lowtemperature alteration and show increased contents of saussuritised plagioclase, chloritised clinopyroxene, and quartz plus calcite within the mesostasis. All intrusions are tholeiitic with moderate levels of $\mathrm{TiO}_{2}(1.56-2.10 \%)$ and $\mathrm{P}_{2} \mathrm{O}_{5}$ $(0.17-0.23 \%)$, and a wide range of $\mathrm{K}_{2} \mathrm{O}(0.25$ $2.73 \%$ ) (Tarakhovskiy et al. 1982, 1983).

The earliest Lower Cretaceous volcanics were erupted on a deeply eroded surface, and rest on rocks ranging in age from Volgian to Rhaetic, and even Lower Carboniferous on George Land (Dibner, 1957, 1970, Dibner \& Krylova, 1963). These early volcanics constitute the Tikhaya Cove formation of NW Hooker Island where they fill in valley-like depressions, up to $50 \mathrm{~m}$ deep. The sequence starts with $8-10$ basalt flows, 1-15 $\mathrm{m}$ thick, which are separated by tuffs. Above these come 5-7 basaltic sheets each with a maximum thickness of $60 \mathrm{~m}$. These are locally overlain by silt- to sand-sized and agglomeratic tuffs which pass upwards into siltstones, clays, carbonaceous clayey shales and minor coal seams. The total thickness is about $280 \mathrm{~m}$ and is dated to Hauterivian-Aptian.

The Salisbury formation, described from Cape Cavagli at the mid-point of the SW side of Salisbury Island, consists of about $260 \mathrm{~m}$ of Aptian-(?) Albian basaltic sheets and coal-bearing sediments. The total thickness of lavas plus sills at this locality is about $600 \mathrm{~m}$.

These two basalt-sediment formations cannot always be traced onto other islands of the archipelago and some local sequences may be usefully noted. At Cape Flora, Northbrook Island, seven basaltic flows reach about $167 \mathrm{~m}$ in thickness and show rude columnar jointing. They are separated by claystones, and siltstones with leaf imprints and, at one horizon, a brown coal bed, $0.5-1.0 \mathrm{~m}$ thick (fig. 3) (Koettlitz 1898; Dibner 1970). Sev- 
eral of our samples were collected at Cape Flora (see below) though the exact locality is unknown.

At Cape Ugolny on the SW side of Hooker Island, the top $40 \mathrm{~m}$ of a sequence of basalt flows is followed by $10 \mathrm{~m}$ of clays and clayey shales and then by $10 \mathrm{~m}$ of a volcanic microbreccia whose top is not exposed (Vlodavetz 1934).

The top of the Cretaceous basalt-sediment sequences is nowhere exposed but it is clear that an extensive basalt plateau must have covered the whole of Franz Josef Land. Widespread dolerite and gabro-dolerite sills and dikes can be largely assigned to the same Cretaceous event.

Most sills are $20-100 \mathrm{~m}$ thick and occur over wide areas. They tend to concentrate at specific stratigraphic horizons such as just beneath the base of the Lower Cretaceous lavas (e.g. Northbrook and Hooker Islands) or between the Wilczekov and Vasil'yevsk, Upper Triassic formations (Wilczekov Land and the islands Hall and Heiss). Different ages for sill emplacement are indicated by the fact that sills on Pritchett and Ziegler Islands were gently interfolded with the host Triassic-Liassic sediments prior to erosion and the extrusion of flat-lying Lower Cretaceous basalts. Sills in deeper strata are not coarser grained than those from higher levels suggesting that they were emplaced at different times but with similar overburdens.

Varying ages are also indicated for the widespread dikes. The main, NW-trending group of dikes usually extend for tens of $\mathrm{km}$ but one was traced for $140 \mathrm{~km}$ across five islands. They are close to vertical, range from a few to $25 \mathrm{~m}$ in width, and were probably feeders to the Lower Cretaceous lava flows. A younger group of dikes with a NE strike are more variable. Some are straight and thin ( $<3-7 \mathrm{~m}$ on Graham Bell Island). Others are curving with varying thickness, i.e. near-surface dikes (Heiss Island). One of these near-surface dikes passes upwards from an amygdaloidal basaltic dolerite to an agglomeratic, vitroclastic tuff in an explosion funnel which may be related to a nearby tuff layer. On other islands, the NE-trending dikes attain thicknesses from c. 15 to $150 \mathrm{~m}$. The youngest dikes of all, with a NW strike, cut Cenomanian sandstones on Hoffmann Island. A wide range of ages for dikes is demonstrated by their relation to cross-cutting sills, themselves of different ages. These various lines of evidence led Dibner (1970) to propose that sills and dikes were intruded from Upper Triassic to post-Cenomanian time, with the most intense period of emplacement taking place in the Lower Cretaceous. This has been confirmed by $\mathrm{K}$-Ar determinations (see above).

An ultrabasic body, about $5 \mathrm{~km}$ across, is tentatively shown as intruding the basalts in the NE part of Salisbury Island (Dibner 1970).

Petrographically, the thinner basaltic flows and the margins of thick flows range from amygdaloidal and hyaline to hyalopilitic. The centres of thicker flows show ophitic and intersertal textures. In slaggy selvages, geoids of calcite and silica minerals occur. Between flows, there are silicified tuffs with plant remains and volcanic bombs up to $0.2 \mathrm{~m}$ across.

The widespread sills and dikes are petrographically similar to the lavas but reach coarser grain sizes - gabbros with ophitic textures. The sills typically possess well-developed vertical or radiating columnar jointing unlike the lavas which have little or no jointing and only in their central part. A $60 \mathrm{~m}$ sill on the $\mathrm{N}$ coast of Wilczek Land contains autometasomatised areas where augite is replaced by hornblende, and also areas of micropegmatite. The NW-trending dike which swells to a thickness of $600 \mathrm{~m}$ to form Rubini Peak (NW coast of Hooker Island) is composed of porphyritic microdolerite with $15-30 \%$ glomeroporphyritic plagioclase, augite and sometimes bronzite.

\section{Tectonics}

Pre-Cretaceous sediments on Franz Josef Land show dome-like upheavals and locally irregular dips up to $10-15^{\circ}$.In contrast, the uncomformably overlying Cretaceous sediments and lavas are more flat-lying and undisturbed. Medium-scale faulting, however, is observed. On Northbrook Island, two NNW-trending faults exhibit downthrows of $40 \mathrm{~m}$ and $200 \mathrm{~m}$ to the ESE (fig. 3). A number of ENE-trending dikes on Wilczek Land show throws of $20-80 \mathrm{~m}$ but without any consistent displacement. On several islands, horizontal shifts of up to $80 \mathrm{~m}$ have been established for faults which cut dikes. The shore lines of many islands are fault-controlled, with the islands representing horsts and the intervening straits representing grabens; these types of faults have throws 
of several hundred metres. These fault systems are thought to have been reactivated at the beginning of the Pleistocene when the continuous landmass of Franz Josef Land was broken up into the present archipelago.

\section{Samples and localities}

Six samples, around 100 grams in weight, were kindly supplied to us by the Department of Mineralogy, British Museum (Natural History), London. Full catalogue numbers and localities are given here, with brief comments:

1905,277(2). Basalt, from talus Cape Flora, Franz Josef Land. Seven lava flows are reported from the cliffs at Cape Flora (Koettlitz 1898); see fig. 3 .

$1905,277(3)$. Basalt, same locality as $277(2)$.

$1905,277(12)$. Basalt, from summit of Cape Flora. See fig. 3.

1905,277(13). Basalt with palagonite from iceberg, Eira Cottage. Collecting samples from uptilted, local icebergs was used to extend rock collections by early Arctic expeditions. Eira Cottage was the hut which B.L. Smith lived in at Cape Flora in the winter of 1881-2.

1905,277(19). Basalt, S. side of Windy Gully, Cape Flora. Windy Gully is a fault-controlled valley between two hills capped by basalt at Cape Flora; see fig. 3.

1905,277(24). Dolerite, from beach at Cape Forbes. This locality, on the SE side of George Island (fig. 2), has several tiers of basalt (Koettlitz 1898).

\section{Present investigations}

Analytical techniques

Minerals were analysed using a JEOL Superprobe JXA-733 (Institute for Mineralogy, Copenhagen University). Major elements were obtained by XRF analysis of glass discs (Greenland Geology Survey) supplemented by atomic absorption $\left(\mathrm{Na}_{2} \mathrm{O}, \mathrm{MgO}\right)$ and wet chemical techniques (FeO, L.O.I.)(Sørensen 1975). Most traces were obtained by XRF analysis (Institute for Petrology, Copenhagen University) directly on powder pellets using a Philips PW 1400 spectrometer. Matrix corrections were performed us- ing major element analyses and published absorption coefficients. Results were standardised against USGS reference materials and synthetic mixtures. Cs, La, Ce, Sm, Eu, Tb, Yb, Lu, Th, $\mathrm{Hf}$, Co and Sc were obtained by INAA, U by delayed neutron counting (both at National Laboratory, Ris $\varnothing$ ), F by a combined distillation-spectrophotometry technique and $\mathrm{Li}$ by atomic absorption.

\section{Petrography}

The six examined specimens from Franz Josef Land show a broad petrographic similarity. They are typically grey, slightly to moderately altered basalts characterised by glomeroporphyritic clusters of plagioclase set in a sub-ophitic matrix which locally shows a dusty, interstitial glass or brownish amygdales. The matrix grades from medium to fine grained, typical for basaltic flows of considerable thickness which have cooled fairly slowly.

Specimen $277-2$ contains $15 \%$ seriate plagioclase microphenocrysts, up to $4 \mathrm{~mm}$ long, which are often in glomeroporphyritic clusters up to 6 $\mathrm{mm}$ across and composed of $2-20$ crystals. The outer grains in the cluster tend to be smaller and anhedral; clinopyroxenes may also be present. Rare clots or microxenoliths of microgabbro, up to $3 \times 6 \mathrm{~mm}$, contain plagioclase and clinopyroxene. Even rarer, clinopyroxene microphenocrysts, up to $0.8 \mathrm{~mm}$ in size, may be gently zoned or fragmented producing sub-grains. The groundmass is sub-ophitic, locally ophitic, and about $0.03 \mathrm{~mm}$ in grainsize. Groundmass plagioclases are more acicular than the microphenocrysts and may show feathery edges and swallow-tail terminations indicative of rapid chilling. Locally, there are very fine-grained, altered patches, probably formed after the finest interstitial groundmass. Skeletal titanomagnetities are concentrated in these areas. Elsewhere, brownish alteration materials have preferentially replaced the groundmass pyroxenes or occur in circular to irregular amygdales.

Sample $277-3$ is very similar, but the amount of plagioclase microphenocrysts and glomeroporphyritic clots is reduced to about $10 \%$. The groundmass probably crystallised in two stages. The first stage (about $0.1 \mathrm{~mm}$ in grain size) con- 
Table 1. Representative analyses of minerals and interstitial glass in Franz Josef Land basalts.

\begin{tabular}{lrrrrrrrrrrr}
\hline & $19-89$ & $3-8$ & $13-94$ & $3-18$ & $12-50$ & $19-36$ & $19-28$ & $2-13$ & $19-108$ & $13-32$ & $24-120$ \\
\hline $\mathrm{SiO}_{2}$ & 37.69 & 48.99 & 59.80 & 51.69 & 51.37 & - & - & 55.82 & 75.09 & 77.41 & 41.15 \\
$\mathrm{TiO}_{2}$ & $<0.02$ & 0.02 & 0.07 & 0.68 & 0.40 & 26.12 & 50.91 & 0.74 & 0.44 & 0.40 & 0.23 \\
$\mathrm{Cr}_{2} \mathrm{O}_{3}$ & $<0.02$ & $<0.02$ & $<0.02$ & 0.35 & 0.03 & $<0.02$ & $<0.02$ & $<0.02$ & $<0.02$ & $<0.02$ & $<0.02$ \\
$\mathrm{Al}_{2} \mathrm{O}_{3}$ & 0.06 & 31.76 & 24.62 & 2.96 & 0.89 & 1.70 & 0.09 & 16.34 & 13.50 & 11.94 & 4.48 \\
$\mathrm{FeO}^{*}$ & 22.66 & 0.61 & 0.69 & 8.57 & 23.66 & 68.33 & 47.68 & 8.67 & 2.32 & 1.41 & 20.13 \\
$\mathrm{MnO}$ & 0.29 & 0.04 & 0.07 & 0.18 & 0.54 & 0.52 & 0.60 & 0.09 & 0.03 & 0.04 & 0.11 \\
$\mathrm{NiO}$ & 0.19 & $<0.02$ & $<0.02$ & $<0.02$ & $<0.02$ & 0.02 & $<0.02$ & $<0.02$ & $<0.02$ & $<0.02$ & $<0.02$ \\
$\mathrm{MgO}$ & 38.55 & 0.23 & 0.06 & 16.25 & 17.79 & 0.64 & 0.59 & 2.82 & 0.36 & 0.13 & 12.94 \\
$\mathrm{CaO}$ & 0.25 & 16.09 & 7.89 & 19.36 & 4.91 & $<0.02$ & $<0.02$ & 5.52 & 1.51 & 1.78 & 2.18 \\
$\mathrm{Na} \mathrm{O}_{2} \mathrm{O}$ & $<0.02$ & 2.56 & 7.43 & 0.32 & 0.21 & - & - & 5.22 & 5.54 & 5.60 & $<0.02$ \\
$\mathrm{~K} \mathrm{O}$ & $<0.02$ & 0.07 & 0.33 & $<0.02$ & $<0.02$ & - & - & 0.42 & 1.24 & 0.89 & $<0.02$ \\
\hline $\mathrm{Sum}$ & 99.69 & 100.37 & 100.96 & 100.36 & 99.80 & 97.90 & 99.99 & 95.64 & 100.03 & 100.20 & 81.22 \\
\hline
\end{tabular}

19-89. Olivine, glomeroporphyrititc clot, $\mathrm{Fo}_{75}$

3-8. Plagioclase, core of large glomeroporphyritic clot, $\mathrm{An}_{7.4} \mathrm{Ab}_{22.2} \mathrm{Or}_{\mathbf{0 . 4}}$.

13-94. Plagioclase, microlite in interstitial glass, $\mathrm{An}_{36.3} \mathrm{Ab}_{61.9} \mathrm{Or}_{1.8}$

3-18. Augite, core of microphenocryst, $\mathrm{Wo}_{39.8} \mathrm{En}_{46.5} \mathrm{Fs}_{13.7}$

12-50. Pigeonite, fine-grained groundmass, $\mathrm{Wo}_{10.2} \mathrm{En}_{51.4} \mathrm{Fs}_{38.4}$

19-36. Titanomagnetite, fine-grained groundmass, $75.95 \%$ Usp, sum includes $0.57 \% \mathrm{~V}_{2} \mathrm{O}_{3}$

19-28. Ilmenite, interstitial glass, $3.99 \% \mathrm{Hm}$, sum includes $0.12 \% \mathrm{~V}_{2} \mathrm{O}_{3}$

2-13. Interstitial glass.

19-108. Interstitial glass.

13-32. Interstitial glass.

24-120. Alteration product of augite (montmorillonite group).

sists of patches of ophitic plagioclase and augite, and is set in the more abundant second stage (about $0.05 \mathrm{~mm}$ in grain size) which lacks even a sub-ophitic texture and contains notable amounts of titanomagnetite and alteration products in addition to plagioclase and augite. Late movements within a cooling basalt flow may have caused the break-up of an early, slowly cooled groundmass causing straining and fragmentation of clinopyroxene microphenocrysts and the more rapid crystallization of the residual liquid.

Sample 277-12 only contains a few percent of plagioclase microphenocrysts up to $2.5 \mathrm{~mm}$ long. These and rare anhedral clinopyroxene microphenocrysts, up to $1.3 \mathrm{~mm}$ long, are set in a groundmass varying from about 0.05 to $0.1 \mathrm{~mm}$ in grain size. Groundmass titanomagnetites occur as simple anhedral or complex skeletal grains.

Sample $277-13$ is an altered, brownish grey basalt with clusters of plagioclase crystals forming about $30 \%$ of the rock. The groundmass shows sharp or gradual transitions between ophitic material $(0.2 \mathrm{~mm}$ grain size) and fine-grained material $(0.05 \mathrm{~mm}$ grain size) containing plagioclase, pyroxene, titanomagnetite, glass and altered patches. The pale brown, dusty glass contains plagioclase, pyroxene and opaque microlites.

Sample $277-19$ is one of the freshest samples, and relics of olivine surrounded by pale brown alteration products can still be seen. They perhaps formed around $1 \%$ of the original rock. Some relic olivine grains, about $0.6 \mathrm{~mm}$ across, occur in the margins of the plagioclase-dominated glomeroporphyritic clots suggesting that crystallization of the olivine took place after the plagioclase but prior to the groundmass stage. Rare clinopyroxene micropenocrysts attain $4 \mathrm{~mm}$ in diameter. The sub-ophitic groundmass, $0.02-0.2 \mathrm{~mm}$ in grain size, is composed of plagioclase, pyroxene and titanomagnetite with interstitial pale brown and partly altered glass. Associated with the glass are ilmenite needles, up to $0.8 \times 0.1 \mathrm{~mm}$ in size, and also grains of titanomagnetite with slightly higher $\mathrm{TiO}_{2}$ contents than the main groundmass titanomagnetites.

Sample $277-24$ is similar to $277-12$ but the groundmass is the coarsest in our collection ranging from 0.1 to $0.5 \mathrm{~mm}$ in grainsize. The rock may thus be termed basaltic dolerite. Much of the groundmass pyroxene has been altered to finergrained secondary products.

The order of crystallization deduced for this suite of samples is microphenocrysts of plagioclase followed by pyroxene \pm olivine, and then medium-grained groundmass plagioclase + pyroxene, fine-grained groundmass plagioclase + 


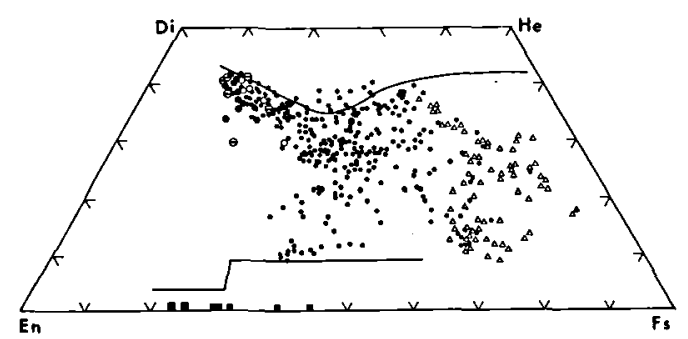

Fig. 4 Pyroxene and olivine quadrilateral for six tholeiites from Franz Josef Land. Circles with bar - pyroxenes from glomeroporphyritic clots and microxenoliths; open circles - pyroxene microphenocrysts; large closed circles-medium-grained groundmass pyroxenes; small closed circles-fine-grained groundmass pyroxenes; open triangles - microlitic pyroxenes in interstitial material; squares-olivines. The equilibrium crystallization trends for high- and low-Ca pyroxenes in the Skaergaard intrusion are from Deer et al. (1978).

pyroxene + titanomagnetite, and finally interstitial glass.

Comparison with previous petrographic descriptions in Newton \& Teall (1897, 1898), Holmes (1918), Bisset (1930), Vlodavetz (1934) and Dibner (1970) indicates that essentially similar basalts and dolerites are common throughout Franz Josef Land and, on petrographic criteria, are the dominant basalt type. Other varieties, not included in our collection but mentioned by Soviet authors, include (a) hyaline or hyalopilitic basalts from thin flows and flow margins, (b) bronzite-bearing basaltic dolerite and (c) various crystal-lithic tuffs and agglomerates (see above).

\section{Mineral chemistry}

Olivine was only present in $277-19$ where it occurs as relics surrounded by a pale brown alteration product. Grains in the margins of glomeroporphyritic clots are $\mathrm{Fo}_{75}$ with $0.17-0.22 \% \mathrm{NiO}$; they probably formed at a late microphenocryst stage (table 1). Scattered through the mediumgrained groundmass, there are olivine relics with $\mathrm{Fo}_{55-70}$ and only $<0.02-0.13 \% \mathrm{NiO}$. The wide range of Fo contents is suggestive of extended groundmass crystallization for olivine or olivine reequilibration, though it was not possible to establish zoning in any of the small relics. Both types of olivine are altered to low-Ca mixtures of saponite and nontronite (see below).

Fe-Ti oxides are absent from the microphenocryst and medium-grained groundmass stages but become more abundant in the fine ground mass and interstitial patches. The $\mathrm{TiO}_{2}$ content of magnetites increases slightly from around $24 \%$ in the fine groundmass to $25-28 \%$ in interstitial grains (table 1). Levels of $\mathrm{Al}_{2} \mathrm{O}_{3}, \mathrm{~V}_{2} \mathrm{O}_{3}, \mathrm{MnO}$ and $\mathrm{MgO}$ are comparable in all these magnetites and, together with the trace amounts of $\mathrm{Cr}_{2} \mathrm{O}_{3}$ $(<0.04 \%)$, are typical of magnetites in evolved tholeiitic basalts described from other localities. In $277-19$, the interstitial magnetites apparently coexist with ilmenite needles with low values for calculated $\mathrm{Fe}_{2} \mathrm{O}_{3}$ (i.e. only $2.9-4.0 \% \mathrm{Hm}$ ). The temperature (c. $890^{\circ} \mathrm{C}$ ) and oxygen fugacity (log $\mathrm{fo}_{2}$, c. -14) deduced for this interstitial stage, using the graphs of Buddington \& Lindsley (1964), fall slightly below the FMQ buffer curve and are comparable to those found in evolved tholeiitic basalts elsewhere.

Plagioclase is present at every stage in the crystallization history of the Franz Josef Land basalts becoming less calcic and more sodic and potassic during crystallization (table 1). The larger plagioclases in the centre of glomeroporphyritic clots have slightly higher An levels $\left(\mathrm{An}_{75-80}\right)$ than the surrounding smaller microphenocrysts $\left(\mathrm{An}_{73-76}\right)$. Delicate oscillatory zoning in these plagioclases lies in the same narrow, compositional range and only thin rims are more sodic. Plagioclases from the medium-grained groundmass $\left(\mathrm{An}_{62-69}\right)$, fine groundmass $\left(\mathrm{An}_{42-55}\right)$ and interstitial glass $\left(\mathrm{An}_{21-39}\right)$ show virtually no overlap in composition. Only the thin rims on plagioclases of each stage presage the composition of crystal cores in the succeeding stage.

$\mathrm{FeO}^{*}$ and $\mathrm{TiO}_{2}$ contents of plagioclase increase from about 0.5 and $0.02 \%$, respectively, in the microphenocryst stage to a maximum of around

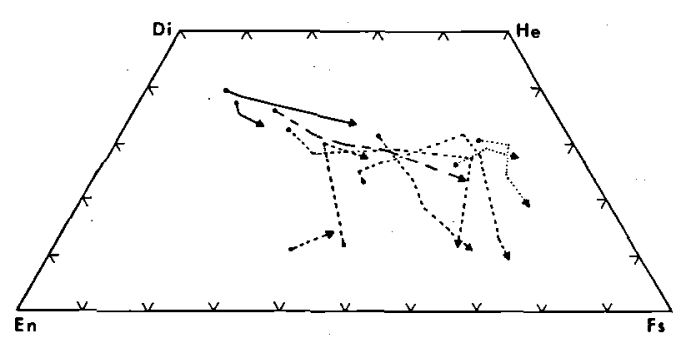

Fig. 5 Pyroxene quadrilateral for six tholeiites from Franz Josef Land showing compositional trends within individual pyroxene grains. Solid lines - pyroxene microphenocrysts; big-dash lines - medium-grained groundmass pyroxenes; small-dash lines fine-grained groundmass pyroxenes; dotted lines-microlitic pyroxenes in interstitial material. 
Table 2. Chemistry of augite-ferroaugite-ferrohedenbergite series (sample 277-13).

\begin{tabular}{|c|c|c|c|c|c|c|c|}
\hline & $13-100$ & 13-116 & $13-88$ & $13-36$ & $13-29$ & $13-25$ & $13-26$ \\
\hline $\mathrm{SiO}_{2}$ & 52.50 & 51.16 & 50.70 & 50.41 & 49.62 & 48.70 & 48.12 \\
\hline $\mathrm{TiO}_{2}$ & 0.56 & 0.87 & 1.03 & 0.91 & 0.88 & 0.81 & 0.84 \\
\hline $\mathrm{Cr}_{2} \mathrm{O}_{3}$ & 0.17 & 0.03 & $<0.02$ & $<0.02$ & $<0.02$ & $<0.02$ & $<0.02$ \\
\hline $\mathrm{Al}_{2} \mathrm{O}_{3}$ & 2.18 & 1.93 & 1.48 & 1.07 & 0.89 & 0.91 & 0.92 \\
\hline $\mathrm{FeO}^{*}$ & 8.81 & 12.15 & 17.07 & 22.90 & 28.06 & 31.33 & 34.95 \\
\hline $\mathrm{MnO}$ & 0.19 & 0.31 & 0.46 & 0.53 & 0.68 & 0.83 & 0.87 \\
\hline $\mathrm{NiO}$ & $<0.02$ & $<0.02$ & $<0.02$ & $<0.02$ & $<0.02$ & $<0.02$ & $<0.02$ \\
\hline $\mathrm{MgO}$ & 16.39 & 14.16 & 13.49 & 11.05 & 7.54 & 4.64 & 1.92 \\
\hline $\mathrm{CaO}$ & 18.85 & 18.55 & 14.95 & 13.10 & 12.62 & 12.27 & 12.90 \\
\hline $\mathrm{Na}_{2} \mathrm{O}$ & 0.27 & 0.31 & 0.31 & 0.27 & 0.19 & 0.26 & 0.25 \\
\hline $\mathrm{K}_{2} \mathrm{O}$ & $<0.02$ & $<0.02$ & 0.08 & $<0.02$ & $<0.02$ & $<0.02$ & 0.02 \\
\hline Sum & 99.92 & 99.47 & 99.57 & 100.24 & 100.48 & 99.75 & 100.79 \\
\hline \multicolumn{8}{|c|}{ Formulae on basis of 60} \\
\hline $\mathrm{Si}$ & 1.941 & 1.933 & 1.941 & 1.958 & 1.970 & 1.982 & 1.977 \\
\hline $\mathrm{Al}^{\mathrm{IV}}$ & 0.059 & 0.067 & 0.059 & 0.042 & 0.030 & 0.018 & 0.023 \\
\hline $\mathrm{Al}^{\mathrm{VI}}$ & 0.036 & 0.019 & 0.008 & 0.007 & 0.012 & 0.026 & 0.022 \\
\hline $\mathrm{Ti}$ & 0.016 & 0.025 & 0.030 & 0.027 & 0.026 & 0.025 & 0.026 \\
\hline $\mathrm{Cr}$ & 0.005 & 0.001 & 0.000 & 0.000 & 0.000 & 0.000 & 0.000 \\
\hline $\mathrm{Fe}^{3+}$ & 0.007 & 0.020 & 0.014 & 0.001 & 0.000 & 0.000 & 0.000 \\
\hline $\mathrm{Fe}^{2+}$ & 0.266 & 0.364 & 0.532 & 0.742 & 0.931 & 1.065 & 1.200 \\
\hline Mn & 0.006 & 0.010 & 0.015 & 0.017 & 0.023 & 0.029 & 0.030 \\
\hline $\mathrm{Ni}$ & 0.000 & 0.000 & 0.000 & 0.000 & 0.000 & 0.000 & 0.000 \\
\hline Mg & 0.903 & 0.798 & 0.770 & 0.640 & 0.446 & 0.282 & 0.118 \\
\hline $\mathrm{Ca}$ & 0.746 & 0.751 & 0.613 & 0.545 & 0.537 & 0.535 & 0.568 \\
\hline $\mathrm{Na}$ & 0.019 & 0.023 & 0.023 & 0.020 & 0.015 & 0.021 & 0.020 \\
\hline $\mathbf{K}$ & 0.000 & 0.000 & 0.004 & 0.000 & 0.000 & 0.000 & 0.001 \\
\hline Z & 2.000 & 2.000 & 2.000 & 2.000 & 2.000 & 2.000 & 2.000 \\
\hline WXY & 2.003 & 2.010 & 2.009 & 2.000 & 1.989 & 1.981 & 1.984 \\
\hline $\mathrm{Fe}_{2} \mathrm{O}_{3}$ & 0.24 & 0.70 & 0.51 & 0.05 & 0.00 & 0.00 & 0.00 \\
\hline $\mathrm{FeO}$ & 8.59 & 11.52 & 16.61 & 22.86 & 28.06 & 31.33 & 34.95 \\
\hline Sum & 99.94 & 99.54 & 99.62 & 100.24 & 100.48 & 99.75 & 100.79 \\
\hline
\end{tabular}

13-100. Augite. Fragmented microphenocryst.

13-116. Augite. Fine-grained groundmass.

13-88. Fe-rich augite. Fine-grained groundmass.

13-36. Fe-poor ferroaugite. Fine-grained groundmass, core.

13-29. Ferroaugite. Same as 13-36, rim.

13-25. Fe-rich ferroaugite. Rim adjacent to interstitial glass.

13-26. Ferohedenbergite. Termination of microlite in glass.

1.0 and $0.15 \%$, respectively, in the fine groundmass. The initiation of copious magnetite crystallization at this stage leads to a decrease of $\mathrm{FeO}^{*}$ and $\mathrm{TiO}_{2}$ in the plagioclase microlites (c. 0.7 and $0.05 \%$, respectively) of the interstitial patches.

Pyroxene cores are augites at the microphenocryst $\left(\mathrm{Fs}_{12-15}\right)$ and medium-grained groundmass stages $\left(\mathrm{Fs}_{12-25}\right)$ with $\mathrm{Cr}_{2} \mathrm{O}_{3}$ contents decreasing from about 0.35 to $0.25 \%$. In contrast, a wide range of compositions is present in the fine groundmass with high-Fe varieties in interstitial material (figs. 4,5; tables 2,3).

The chemistry of Ca-rich pyroxenes occurring as microphenocrysts, glomeroporphyritic clots, microxenoliths and fragmented "micropheno- crysts" (see Petrography) are indistinguishable indicating that these textural variants crystallised at essentially the same stage from the sampled basaltic magmas.

Some groundmass crystals show pyroxene trends comparable to equilibrium liquidus pyroxenes in slowly cooled tholeiitic intrusions (e.g. Skaergaard, Bushveld) and fractionated tholeiitic lava series (e.g. Thingmulí) (reviewed by Deer et al. 1978)(fig.4). Thus these augites show an early decrease in $\mathrm{Ca}$ followed by nearly constant $\mathrm{Ca}$ combined with $\mathrm{Fe}$ enrichment, a trend which finishes in the ferroaugite field. The rims of these grains, if they abut against interstitial material, may continue the trend into ferrohedenbergite. 
Table 3. Chemistry of augite-ferroaugite-subcalcic ferroaugite-ferriferous pigeonite series (sample 277-19).

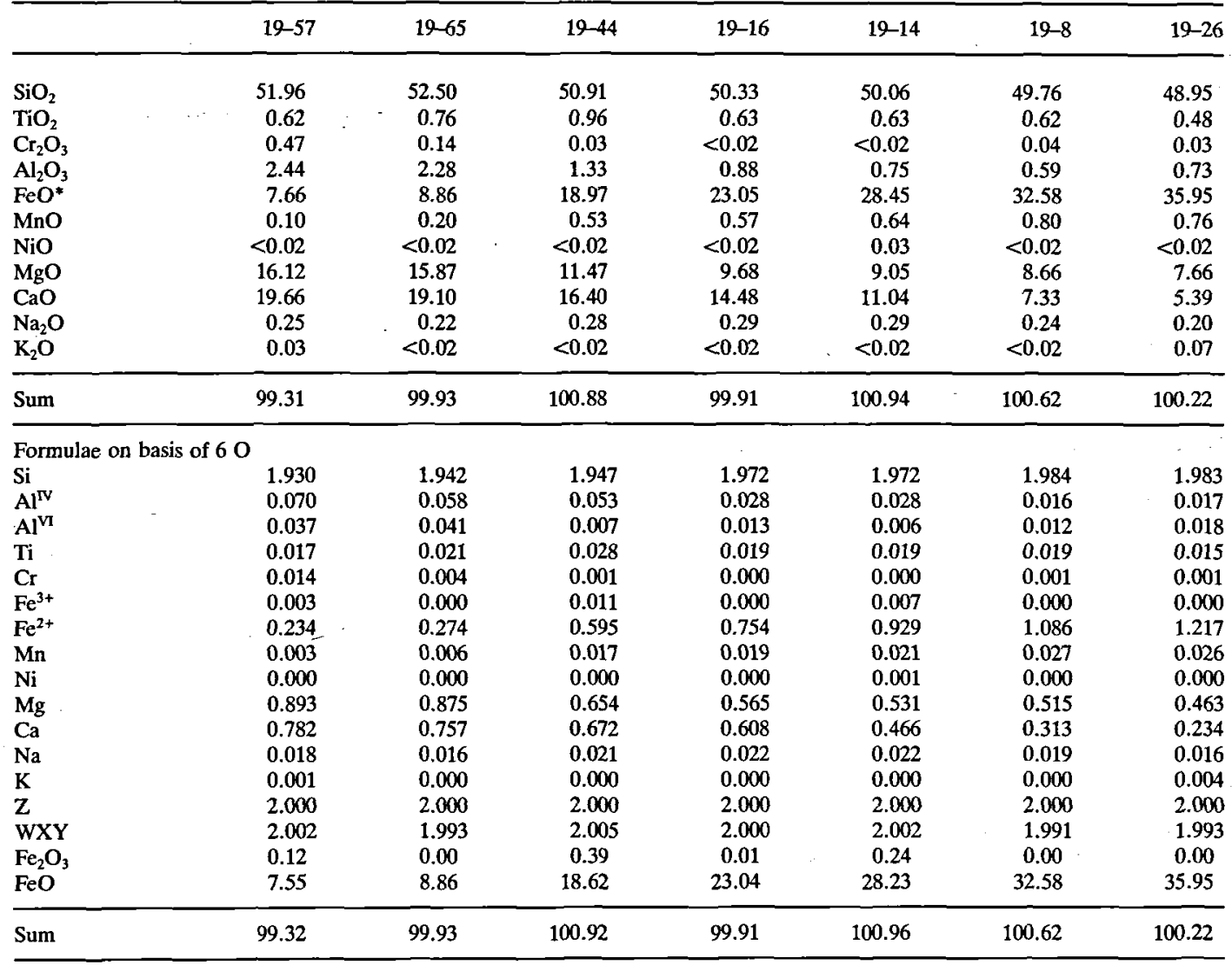

19-57. Augite. Medium-grained groundmass.

19-65. Augite. Medium-grained groundmass.

19-44. Fe-rich augite. Fine-grained groundmass.

19-16. Ferroaugite. Fine-grained groundmass, core.

19-14. Fee-poor subcalcic ferroaugite. Same as 19-16, intermediate zone.

19-8. Fe-rich subcalcic ferroaugite. Same as 19-16, rim.

19-26. Ferriferous pigeonite. Microlite in interstitial glass.

However, most rims show a sharp decrease in $\mathrm{Ca}$ so that compositions pass through subcalcic ferroaugite to ferriferous pigeonite. The initiation of the sharply decreasing $\mathrm{Ca}$, and the $\mathrm{Ca}: \mathrm{Fe}: \mathrm{Mg}$ ratios observed during the decrease, vary widely both within and between the studied samples. It is thus clear that different micro-environments were established during the final stages of crystallization, and are related to the appearance of isolated interstitial residual liquids. Fe-rich rims are in chemical and optical continuity with crystal cores in nearly all cases; only two examples were observed where the rim showed a sharp contact with the main crystal.

Pigeonite, of intermediate composition, has only been found in two of the six samples (277-12 and 277-13). Even here, it is comparatively rare, being $10 \%$ of the groundmass pyroxenes in $277-12$ and only $4 \%$ in $277-13$. It is never found in medium-grained groundmass or interstitial material, only in fine groundmass. Single crystals of pigeonite may be gently zoned from low-Ca to higher-Ca and higher-Fe pigeonite, followed by a sharp increase in Ca so that they pass through the subcalcic fields and into augite or ferroaugite. Additional zoning, present where grains were in contact with interstitial liquid, follows the trends mentioned above, i.e. to Fe-rich compositions such as ferriferous pigeonite. Compositions which directly join intermediate pigeonites to fer- 
Table 4. Chemical compositions and norms of basalts from Franz Josef Land, U.S.S.R.

\begin{tabular}{|c|c|c|c|c|c|c|}
\hline & 24 & 19 & 12 & 2 & 3 & 13 \\
\hline $\mathrm{SiO}_{2}$ & 49.12 & 49.29 & 49.23 & 48.87 & 48.97 & 48.95 \\
\hline $\mathrm{Al}_{2} \mathrm{O}_{3}$ & 15.89 & 14.90 & 14.24 & 15.41 & 15.08 & 15.54 \\
\hline $\mathrm{Fe}_{2} \mathrm{O}_{3}$ & 5.99 & 2.71 & 4.41 & 3.78 & 4.39 & 5.26 \\
\hline $\mathrm{FeO}$ & 4.91 & 8.79 & 8.41 & 8.15 & 7.98 & 6.83 \\
\hline $\mathrm{MnO}$ & 0.17 & 0.21 & 0.21 & 0.27 & 0.24 & 0.21 \\
\hline $\mathrm{MgO}$ & 6.52 & 6.72 & 6.58 & 5.75 & 5.78 & 5.55 \\
\hline $\mathrm{CaO}$ & 11.07 & 11.47 & 11.13 & 11.78 & 11.59 & 10.96 \\
\hline $\mathrm{Na}_{2} \mathrm{O}$ & 2.41 & 2.27 & 2.49 & 2.25 & 2.35 & 2.56 \\
\hline $\mathrm{K}_{2} \mathrm{O}$ & 0.14 & 0.19 & 0.18 & 0.14 & 0.13 & 0.16 \\
\hline $\mathrm{TiO}_{2}$ & 1.31 & 1.69 & 1.75 & 1.76 & 1.85 & 1.76 \\
\hline P2O5 & 0.10 & 0.12 & 0.15 & 0.14 & 0.15 & 0.16 \\
\hline L.O.I. & 2.04 & 1.42 & 1.58 & 1.49 & 1.58 & 1.82 \\
\hline Sum & 99.67 & 99.78 & 100.36 & 99.79 & 100.09 & 99.76 \\
\hline $\mathrm{FeO}^{*}$ & 10.30 & 11.23 & 12.38 & 11.55 & 11.93 & 11.56 \\
\hline $\mathrm{FeO}^{*} / \mathrm{MgO}$ & 1.58 & 1.67 & 1.88 & 2.01 & 2.06 & 2.08 \\
\hline \multicolumn{7}{|c|}{ CIPW weight norm calculated volatile-free and with $\mathrm{Fe}_{2} \mathrm{O}_{3} / \mathrm{FeO}$ adjusted to 0.15} \\
\hline $\mathbf{Q}$ & - & - & - & 0.52 & 0.34 & 0.11 \\
\hline OR & 0.85 & 1.14 & 1.08 & 0.85 & 0.78 & 0.97 \\
\hline $\mathrm{AB}$ & 21.01 & 19.58 & 21.40 & 19.42 & 20.26 & 22.23 \\
\hline AN & 33.10 & 30.48 & 27.58 & 32.18 & 30.79 & 31.24 \\
\hline DI & 19.31 & 22.65 & 23.04 & 22.31 & 22.67 & 20.15 \\
\hline HY & 20.59 & 20.60 & 18.72 & 18.86 & 19.09 & 19.50 \\
\hline OL & 0.53 & 0.08 & 2.17 & - & - & - \\
\hline MT & 2.03 & 2.19 & 2.41 & 2.25 & 2.33 & 2.28 \\
\hline IL . & 2.57 & 3.27 & 3.37 & 3.41 & 3.58 & 3.43 \\
\hline AP & 0.23 & 0.28 & 0.35 & 0.33 & 0.35 & 0.37 \\
\hline
\end{tabular}

Samples collected by Jackson-Harmsworth Expedition, British Museum (Cat. 1905, 277).

riferous pigeonites have not been found, and are almost certainly absent.

Microlitic pyroxenes in interstitial material are always highly ferriferous. The cores of the larger microlites are $\mathrm{Fe}$-rich ferroaugite whereas rims are even richer in $\mathrm{Fe}$ and usually much poorer in $\mathrm{Ca}$ (ferrohedenbergite, subcalcic ferroaugite, ferriferous pigeonite, plus unnamed pyroxenes; see fig. 5).

Because of the exceptionally wide range in the chemistry of groundmass pyroxenes, we have documented the continuity in composition between augite and ferrohedenbergite (table 2) and between augite and ferriferous pigeonite (table 3). Both series show a steady decrease in $\mathrm{SiO}_{2}$, $\mathrm{Cr}_{2} \mathrm{O}_{3}, \mathrm{Al}_{2} \mathrm{O}_{3}$ and $\mathrm{MgO}$ but an increase in $\mathrm{FeO}$ and $\mathrm{MnO}$. Levels of $\mathrm{Na}_{2} \mathrm{O}$ are more or less constant. $\mathrm{TiO}_{2}$ contents culminate at the stage of fine grained groundmass and then decrease at the interstitial stage. Levels of $\mathrm{Al}_{2} \mathrm{O}_{3}$ are relatively low and $\mathrm{SiO}_{2}$ relatively high, typical of tholeiitic magmas with relatively high $a \mathrm{SiO}_{2}$ (Deer et al. 1978: 340). The structural formulae reveal an increase in $\mathrm{Si}$ (dependent on the decrease in $\mathrm{Al}_{2} \mathrm{O}_{3}$ ), minor or zero levels of $\mathrm{Fe}^{3+}$ and a slight tendency for vacancies in the WXY site as both series evolve.

The groundmass pyroxene variations documented for the six Franz Josef Land basalts reflect both equilibrium and metastable ("quench") crystallization (reviewed by Deer et al. 1978). Based on comparisons with intrusions and lava series with variable cooling rates, equilibrium crystallization seems evident during crystallization of the medium-grained groundmass and most of the fine groundmass. It probably terminated when the pigeonite in the two-pyroxene assemblages (pigeonite and augite) became unstable. Subsequent metastable crystallization probably best explains (a) the rims of sub-calcic augite and ferroaugite on pigeonites; these rims probably crystallised at a late stage of the fine groundmass crystallization, and (b) the rapid changes from ferroaugite to ferriferous pigeonites from pyroxenes crystallising in or adjacent to interstitial liquids. Micro-enviroments with var- 
Table 5. Trace-element analyses of basalts from Franz Josef Land, U.S.S.R.

\begin{tabular}{|c|c|c|c|c|c|c|}
\hline & 24 & 19 & 12 & 2 & 3 & 13 \\
\hline Cs & $<0.1$ & 0.47 & $<0.2$ & $<0.1$ & $<0.2$ & $<0.2$ \\
\hline $\mathrm{Rb}$ & 1.1 & 5.8 & 1.4 & 2.4 & 3.8 & 1.0 \\
\hline $\mathrm{Ba}$ & 64 & 67 & 99 & 48 & 53 & 65 \\
\hline $\mathrm{Pb}$ & 1.7 & 2.1 & 1.4 & 1.1 & 0.6 & 2.7 \\
\hline Sr & 237 & 188 & 191 & 207 & 215 & 200 \\
\hline $\mathbf{L a}$ & 6.8 & 8.0 & 8.0 & 8.1 & 9.5 & 9.6 \\
\hline $\mathrm{Ce}$ & 17.0 & 20.0 & 19.3 & 19.9 & 22.4 & 23.6 \\
\hline Nd & 11 & 13 & 11 & 13 & 15 & 15 \\
\hline $\mathrm{Sm}$ & 3.13 & 3.76 & 3.32 & 3.82 & 4.38 & 4.39 \\
\hline $\mathrm{Eu}$ & 1.13 & 1.43 & 1.26 & 1.51 & 1.58 & 1.60 \\
\hline $\mathrm{Tb}$ & 0.64 & 0.83 & 0.80 & 0.90 & 0.89 & 0.93 \\
\hline $\mathrm{Yb}$ & 1.97 & 2.63 & 2.70 & 2.91 & 2.57 & 2.89 \\
\hline $\mathrm{Lu}$ & 0.29 & 0.39 & 0.43 & 0.42 & 0.39 & 0.44 \\
\hline$Y$ & 23 & 31 & 30 & 31 & 33 & 33 \\
\hline Th & 0.77 & 0.78 & 0.36 & 0.59 & 1.29 & 1.60 \\
\hline $\mathrm{U}$ & 0.30 & 0.30 & 0.27 & 0.33 & 0.37 & 0.39 \\
\hline $\mathrm{Zr}_{\mathbf{r}}$ & 80 & 108 & 99 & 110 & 118 & 112 \\
\hline Hf & 2.37 & 3.24 & 2.46 & 3.17 & 3.28 & 3.17 \\
\hline Sn & 1.6 & 1.5 & 1.6 & 1.5 & 1.4 & 1.7 \\
\hline Mo & 1.5 & 0.7 & 0.3 & $<0.2$ & 0.5 & 0.4 \\
\hline $\mathrm{Nb}$ & 6.3 & 8.8 & 7.7 & 8.2 & 9.1 & 7.5 \\
\hline $\mathrm{Ta}$ & 0.23 & 0.35 & 0.27 & 0.39 & 0.39 & 0.32 \\
\hline $\mathrm{Li}$ & 4 & 5 & 5 & 5 & 5 & 5 \\
\hline $\mathrm{Zn}$ & 82 & 93 & 104 & 95 & 103 & 108 \\
\hline $\mathrm{Cu}$ & 128 & 163 & 190 & 177 & 198 & 189 \\
\hline Co & 44 & 45 & 39 & 44 & 44 & 43 \\
\hline $\mathrm{Ni}$ & 79 & 103 & 74 & 93 & 65 & 60 \\
\hline Sc & 37 & 41 & 36 & 40 & 44 & 39 \\
\hline V & 102 & 352 & 101 & 146 & 134 & 142 \\
\hline $\mathrm{Cr}$ & 128 & 262 & 138 & 214 & 136 & 93 \\
\hline As & $<0.5$ & 0.5 & $<0.5$ & $<0.5$ & 0.9 & $<0.5$ \\
\hline $\mathrm{Ga}$ & 17 & 16 & 18 & 17 & 18 & 18 \\
\hline $\mathrm{Ge}$ & 1.4 & 1.5 & 1.5 & 1.5 & 1.5 & 1.4 \\
\hline S & 190 & 520 & 120 & 370 & 800 & 1900 \\
\hline $\mathrm{Cl}$ & 120 & 85 & $<5$ & 20 & s0 & 310 \\
\hline F & 195 & 192 & 178 & 172 & 231 & 211 \\
\hline
\end{tabular}

Analysts: J. C. Bailey, R. Gwozdz, H. Kunzendorf, B. Møller

iable chemical and physical parameters, and related to formation of trapped pockets of interstitial liquid, were developed so that the final pyroxene trends vary even in an area of a few square $\mathrm{cm}$.

Interstitial glass has been preserved in three of the samples (table 1). In 277-2, there are a few patches which appear to have suffered only minor hydration. They are of intermediate composition $\left(55-56 \% \quad \mathrm{SiO}_{2}\right)$ with relatively low $\mathrm{TiO}_{2}(0.6-$ $0.8 \%$ ). Interstitial glass, variably devitrified, is widely preserved in 277-13 and 277-19; in both cases it is rhyolitic with a high $\mathrm{Na} / \mathrm{K}$ ratio, a feature inherited from the starting basalt compositions.

Alteration products occur in every studied thin section. According to X-ray diffraction studies, the alteration material is some variety of the montmorillonite group. Ca-rich pyroxenes are converted to a reddish-brown, Ca-poor $(1.5-2.5 \% \mathrm{CaO})$ mixture of nontronite $>$ saponite with increased $\mathrm{Al}_{2} \mathrm{O}_{3}, \mathrm{FeO}^{*}, \mathrm{~K}_{2} \mathrm{O}$ and $\mathrm{H}_{2} \mathrm{O}$ over the starting pyroxene; $\mathrm{SiO}_{2}, \mathrm{CaO}, \mathrm{MgO}$ and $\mathrm{Na}_{2} \mathrm{O}$ show a decrease. $\mathrm{H}_{2} \mathrm{O}$ contents vary from about $5-19 \%$. With increasing $\mathrm{H}_{2} \mathrm{O}$, the levels of all constituents decrease except for $\mathrm{MgO}, \mathrm{CaO}$ and the somewhat erratic $\mathrm{K}_{2} \mathrm{O}$ (table 1). Olivine is altered to a pale brown mixture of saponite $>$ nontronite with virtually no $\mathrm{Ca}(0.1-0.3 \% \mathrm{CaO})$. The montmorillonite in several amygdales is chemically similar to the augite alteration product.

Altered brown glass in 277-2 shows a marked increase in $\mathrm{H}_{2} \mathrm{O}$ and $\mathrm{FeO}^{*}$ at the expense of the original $\mathrm{SiO}_{2}, \mathrm{Al}_{2} \mathrm{O}_{3}$ and $\mathrm{Na}_{2} \mathrm{O}$. Such material is on the way to palagonite in composition though 


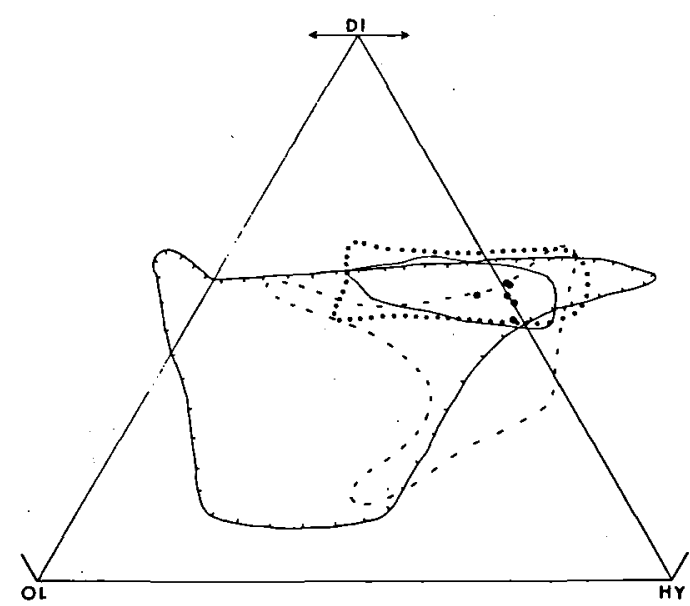

Fig. 6 Basalt saturation diagram for tholeiites from Franz Josef Land (filled circles). Fields for N-MORB (dotted line) and Siberian continental tholeiites (dashed line) are from BVSP (1981); initial rifting basalts from northern E Greenland (continuous line with side bar) are from Upton et al. (1984).

true palagonite as recorded in many glassy basalts from Franz Josef Land (e.g. Newton \& Teall 1897) was not found in the present collection. Alteration of the rhyolitic interstitial glasses in $277-13$ and $277-19$ is confined to hydration plus loss of $\mathrm{Na}_{2} \mathrm{O}$ and this coincides with a sharp gain in $\mathrm{K}_{2} \mathrm{O}$.

Amygdales are rarely present in the six studied samples; they are filled with montmorillonite. Earlier writers refer to locally abundant amygdales of "palagonite", "chlorophaeite", calcite, analcime, natrolite, agate, chalcedony, quartz and iddingsite-bowlingite (Newton \& Teall 1897; Bisset 1930; Dibner 1970).

\section{Chemistry}

Major elements, CIPW norms and trace-element data are presented for the six samples, organised according to increasing $\mathrm{FeO} / \mathrm{MgO}$, in tables 4,5 . The samples are all tholeiitic basalts, and straddle the line of quartz saturation in the basalt tetrahedron (fig. 6) with less than $2.5 \%$ normative quartz or olivine. In this respect, they resemble evolved tholeiitic basalts from many different tectonic settings. The evolved character is also seen on the FMA triangle (fig. 7) where they are displaced towards the $\mathrm{FeO}^{*}$ apex, and in their relatively high $\mathrm{FeO}^{*} / \mathrm{MgO}$ ratios (1.58-2.08).

Nevertheless, the Franz Josef Land tholeiites

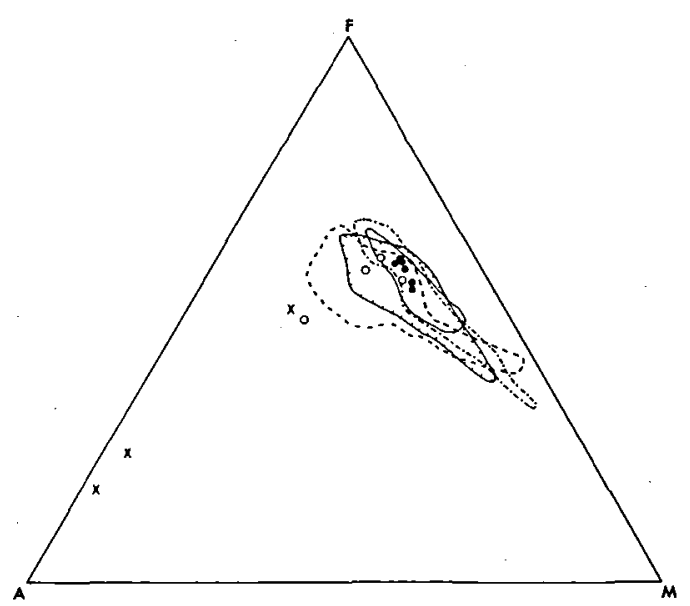

Fig. 7 FMA triangle for six Lower Cretaceous tholeiites (filled circles) and their interstitial glass (crosses) from Franz Josef Land. Pre-Cretaceous intrusives on Franz Josef Land (open circles) are from Tarachovskii et al. 1983. Initial rifting basalts from northern $E$ Greenland (continuous line with side bar) are from Upton et al. (1984); from Scoresby Sund region, E Greenland (continuous line) are from Larsen et al. (in press); from lower and middle series, Faeroe Islands (dash-dot line) are from Hald \& Waagstein (1984) and Waagstein \& Hald (1984), continental tholeiite traps from Siberia (dashed line) are from BVSP (1981).

are not Fe-rich. Their range of $\mathrm{FeO}^{*}(10.30$ $12.38 \%$ ) is below values typical for Fe-rich basalts, e.g. the FeTi basalts of the N. Altantic Tertiary-Recent province (12.5-15.5\% FeO*)(Brooks \& Jakobsson 1974). Similarly, $\mathrm{TiO}_{2}$ is relatively low (1.31-1.85\%) compared to FeTi basalts (typically $2-3.5 \% \mathrm{TiO}_{2}$ ). In terms of $\mathrm{FeO}^{*}$ and $\mathrm{TiO}_{2}$, the Franz Josef Land tholeiites resemble MORB and certain low-FeTi initial rifting tholeiites

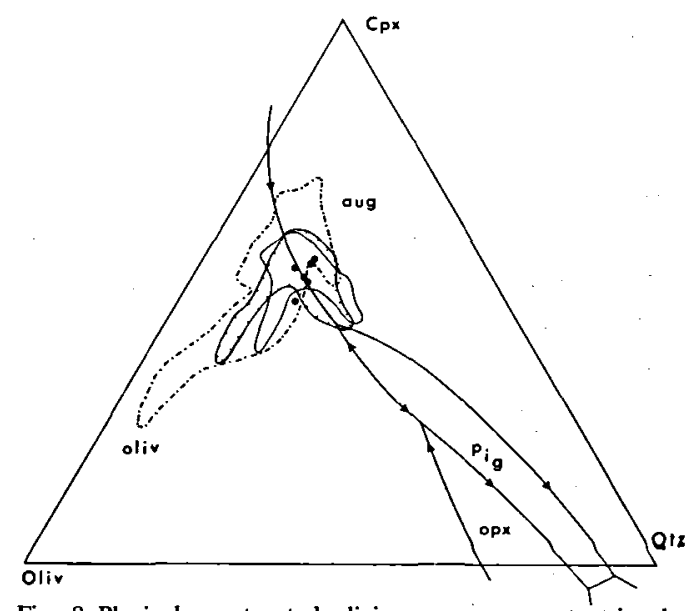

Fig. 8 Plagioclase-saturated olivine-pyroxene-quartz triangle (Grove \& Baker 1984). Symbols are the same as in Fig. 7. 


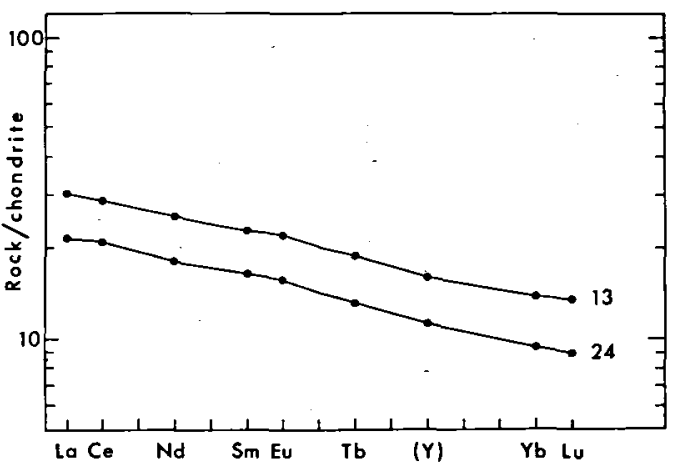

Fig. 9 Chondrite-normalised REE patterns of Franz Josef Land tholeiites illustrating the extreme range of absolute contents (samples 24 and 13). Normalising values are from Leedey chondrite data (Masuda et al. 1973) divided by 1.20.

(IRT) from E. Greenland (Upton et al. 1984; Larsen et al., in press). The similarity to these two types of basalts is confirmed by relatively high $\mathrm{SiO}_{2}$ and $\mathrm{Al}_{2} \mathrm{O}_{3}$ contents, and by the $\mathrm{H}$ element pattern (see below).

The evolved character of the Franz Josef Land tholeiites is also seen on the plagioclase-saturated olivine-pyroxene-quartz triangle (fig. 8) (Grove \& Baker, 1984) where they lie around the olivineaugite cotectic. Saturation of the Franz Josef Land tholeiites in plagioclase, augite and olivine has already been inferred from petrographic observations.

Trace-element analyses confirm the evolved character of the Franz Josef Land tholeiites since the $\mathrm{Cr}$ and $\mathrm{Ni}$ contents are moderately low, falling below values indicative of primary magmas from the upper mantle (400-600 ppm $\mathrm{Cr}, 300-450$ ppm Ni).

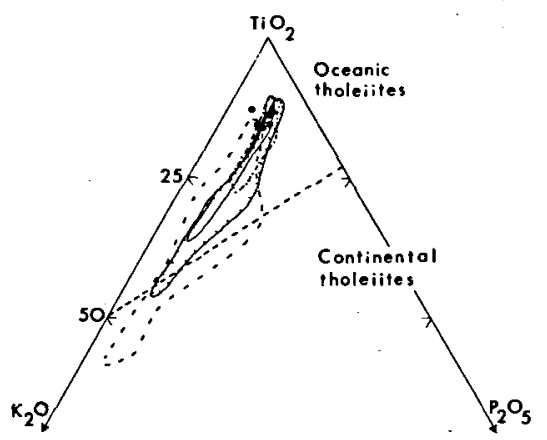

Fig. 10 The $\mathrm{TiO}_{2}-\mathrm{P}_{2} \mathrm{O}_{5}-\mathrm{K}_{2} \mathrm{O}$ diagram of Pearce et al. (1975) discriminating between oceanic (including initial rifting) and continental (true within-plate) non-alkaline basalts. Symbols are the same as in Fig. 7.

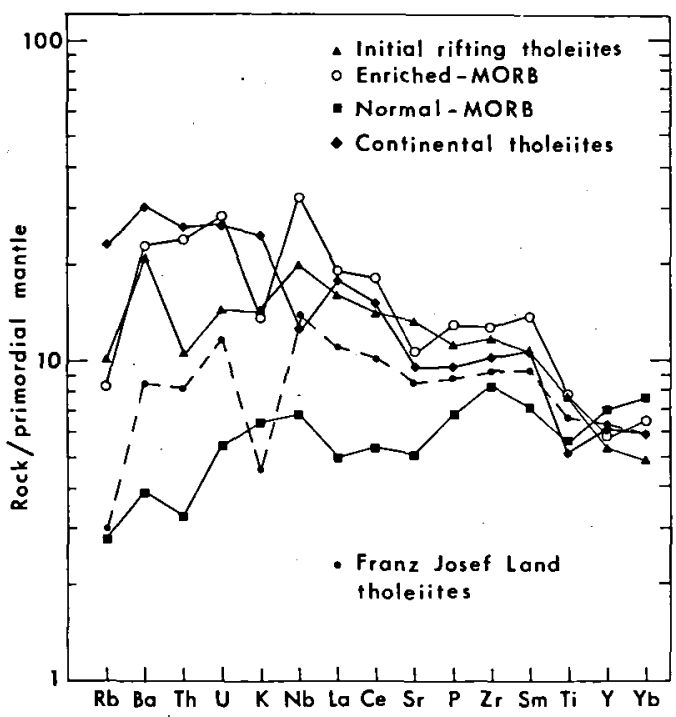

Fig. $11 \mathrm{H}$-element pattern for Franz Josef Land tholeiites showing its similarity to pattern for initial rifting tholeiites. Patterns for tholeiites from different tectonic settings were compiled by Holm (1985). Primordial mantle from Wood et al. (1979).

The six samples show a narrow range of fractionation within a single comagmatic suite. With increasing $\mathrm{FeO}^{*} / \mathrm{MgO}$, levels of $\mathrm{MnO}, \mathrm{TiO}_{2}$, $\mathrm{P}_{2} \mathrm{O}_{5}, \mathrm{REE}, \mathrm{Th}, \mathrm{U}, \mathrm{Zr}, \mathrm{Hf}, \mathrm{Nb}, \mathrm{Zn}, \mathrm{Cu}, \mathrm{V}$ and $\mathrm{F}$ also tend to increase slightly, whereas $\mathrm{MgO}, \mathrm{Ni}$ and $\mathrm{Cr}$ all decrease. These are the normal trends associated with low P-T fractionation of tholeiitic magmas. Even higher values for $\mathrm{FeO}^{*} / \mathrm{MgO}$ (3.59) and $\mathrm{TiO}_{2}(2.88 \%)$ were recorded in a tholeiitic basalt from Cape Ugolny, Hooker Island, described by Vlodavetz (1934).

All six samples reveal similar trace element

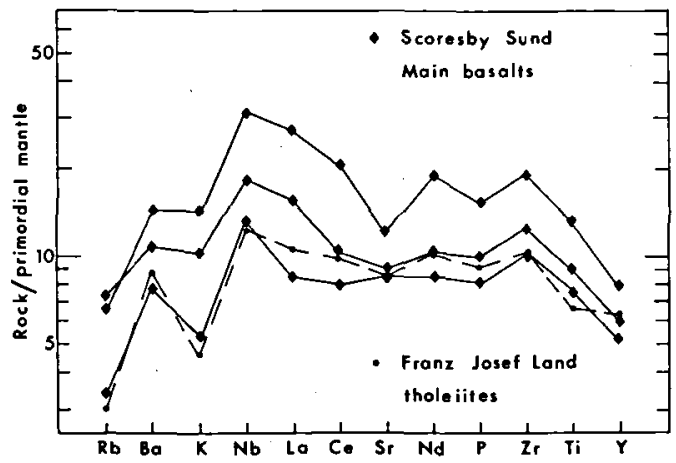

Fig. 12 Partial H-element pattern for Franz Josef Land tholeiites showing its similarity to the low-Ti, initial rifting tholeiites from the Scoresby Sund region, E Greenland (Larsen et al., in press). Primordial mantle from Wood et al. (1979). 
patterns. Contents of many $\mathrm{H}$-elements are distinctly low. Thus the average contents of $\mathrm{K}_{2} \mathrm{O}$ and $\mathrm{Rb}(0.14 \%$ and $2.6 \mathrm{ppm}$, respectively) are comparable to levels in normal-MORB (NMORB, av. $0.20 \%, 2.42 \mathrm{ppm}$ ) and distinctly less than in enriched-MORB (E-MORB, av. $0.42 \%$, $7.3 \mathrm{ppm}$ ) (compilation of Holm (1985)). Compared to E-MORB and IRT, the Franz Josef Land tholeiites possess relatively low $\mathrm{Ba}, \mathrm{Th}, \mathrm{U}$, $\mathrm{Nb}, \mathrm{REE}, \mathrm{Sr}, \mathrm{P}$ and $\mathrm{Ti}$.

All REE patterns are closely similar and show a steady decrease from $\mathrm{La}$ to $\mathrm{Lu}$ (fig. 9). Absolute contents of REE tend to increase with fractionation but there is no consistent change in the pattern. Eu anomalies are not obviously present; the small computed positive anomaly lies within our analytical uncertainties.

\section{Tectonic setting}

The $\mathrm{TiO}_{2}-\mathrm{P}_{2} \mathrm{O}_{5}-\mathrm{K}_{2} \mathrm{O}$ diagram of Pearce et al. (1975) has proved useful is separating tholeiites with oceanic and continental affinities. These authors and Holm (1985) have emphasised that tholeiites with oceanic affinities include N-MORB, E-MORB and also IRT even though the latter may be erupted on continental crust as in E. Greenland. Fig. 10 shows that the Franz Josef Land tholeiites can be assigned to this "oceanic" group.

A better discrimination of tectonic settings is achieved by H-element patterns (Holm 1985). The overall shape of these patterns and the occurrence of anomalies for certain elements are considered more diagnostic than the absolute level for the pattern. The absolute level is partly dependent on the degree of partial melting and subsequent fractional crystallization, i.e. features unrelated to tectonic setting.

The Franz Josef Land pattern (fig. 11) differs from the ocean-floor basalt (N-MORB) pattern which is characterised by a positive slope tending to flatten out to the right. It also differs, though erupted on continental crust, from the true continental tholeiites (i.e. within-plate basalts) such as the nearby Siberian Plateau basalts (BVSP 1981) which show an overall negative slope with a negative $\mathrm{Nb}$ anomaly. The two nearest patterns are those from E-MORB and IRT. Both have a negative slope over much of the pattern and a posi- tive $\mathrm{Nb}$ anomaly. However, the IRT lack (a) the positive Th-U anomaly, (b) the pronounced, positive $\mathrm{Nb}$ anomaly relative to $\mathrm{U}$ and $\mathrm{La}$, (c) the negative $\mathrm{Sr}$ anomaly and (d) the positive slope between $\mathrm{Y}$ and $\mathrm{Yb}$ which characterise the $\mathrm{E}$ MORB pattern. The Franz Josef Land tholeiites likewise lack all these features and may thus be assigned to the initial rifting tholeiites.

A few words of caution may be given at this point. Firstly, only four localities were available to Holm (1985) in his compilation of IRT. Secondly, the absolute level of many H-elements in the Franz Josef Land pattern is lower than in the IRT pattern. This cannot be explained by the fairly advanced level of fractionation within the Franz Josef Land tholeiites which would tend to increase absolute contents. In fact, while recent work by Upton et al. (1984) and Larsen et al. (in press) has confirmed the $\mathrm{H}$-element pattern for IRT proposed by Holm (1985), these authors have found considerable variations in the absolute levels of $\mathrm{H}$-elements. The Franz Josef Land tholeiites have been plotted on the partial $\mathrm{H}$ element patterns of these authors, and are seen to be similar to those IRT with low (or low to medium) contents of $\mathrm{H}$-elements (fig. 12).

Upton et al. (1984) consider that the IRT with low H-element contents in northern $\mathrm{E}$ Greenland have a temporal significance: they were the final initial rifting basalts prior to the onset of oceanfloor spreading and the eruption of MORB. Further to the south in E Greenland, in the Scoresby Sund region, IRT with low H-element contents also appeared. However, in this region, Larsen et al. (in press) consider that these depleted IRT may also develop in rifting episodes that fail, i.e. episodes where oceanic crust does not appear and where the magmatism waned and died. Nevertheless, this failed rifting was coeval with the Lower Tertiary successful rifting and ocean-floor development at somewhat greater distances, south of the proto-Iceland region. It is worth noting that the time interval between these Lower Tertiary failed rifts and the start of successful, major ocean-floor spreading north of Iceland during the early Miocene is about $30-35$ million years. 


\section{Petrogenesis}

Given the limited geological background to our samples and their restricted provenance, we only discuss a single aspect of their petrogenesis - the geochemical character of the mantle source.

The following features indicate that the mantle source for the Franz Josef Land tholeiites had a more depleted character than the average IRT source (Holm 1985):

(a) the overall low content of H-elements,

(b) the $\mathrm{Zr} / \mathrm{Nb}$ ratio of 13.2 is higher than in the average IRT (10.4) and approaches the ratio in N-MORB (22.1),

(c) the average $\mathrm{La} / \mathrm{YbN}$ ratio of 2.12 is distinctly lower than in the average IRT (3.62) and approaches the ratio in N-MORB (0.72),

(d) the average $K / \mathrm{Rb}$ ratio of 755 is higher than the average for IRT (440) and closer to that for N-MORB (690),

(e) the $\mathrm{Rb} / \mathrm{Sr}$ ratio average $(0.013)$ is lower than in IRT $(0.026)$ and similar to N-MORB (0.020).

Thus the Franz Josef Land tholeiites and their mantle source have a depleted trace-element character with features approaching, but certainly not the same as, those in N-MORB sources which are agreed to be depleted mantle (e.g. BVSP 1981). It is unclear whether the total geochemical pattern of these "depleted" IRT is attributable solely to the mantle source. The possibility must also be considered that contamination by continental crust also plays a role. This is more appropriately discussed when a greater sample coverage of Franz Josef Land basalts becomes available and is combined with elemental and isotopic analysis of these basalts and the underlying continental crust.

\section{Discussion}

A century ago, at the moment when Jackson and Nansen unexpectedly met on the ice near Cape Flora, their two expeditions had already established the geological setting of Franz Josef Land an archipelago of platform sediments and basalts located on the Barents continental shelf immediately south of the deep Arctic Ocean basin. Mod- ern geologists, with the widespread acceptance of a rifting origin for the major ocean basins and for their initial and on-going volcanism, would $a$ priori assign the Franz Josef Land basalts to an event associated with rifting of the Arctic Ocean floor. Thus, our conclusion, based on geochemical analogies, that the tholeiites of Franz Josef Land are initial rifting tholeiites, i.e. tholeiites erupted on continental crust during the early stages of opening of an ocean basin, is consistent with modern concepts about their geological setting.

The significance of the Lower Cretaceous age for the Franz Josef Land tholeiites can only be understood after reviewing the Mesozoic-Tertiary history of the Artic Ocean basin. Three stages in the opening of this basin have been suggested by recent studies (see fig. 1 for localities):

(1) A period of extensional tectonics led to the opening of the Canada Basin about 128-113 myBP (Lower Cretaceous). Hubbard et al. (1987) hypothesise a left-lateral transport of Artic Alaska as a seperate microplate past Artic Canada. Northern Alaska was thus juxtaposed to the Lomonosov Ridge which was part of the Barents Shelf at this time. Other authors have proposed a rotational opening of the Canada Basin (Tailleur 1973; Harland et al. 1984). This would have moved the NW part of Alaska, the NE corner of Siberia and the Chukchi plateau away from the Barents Shelf.

(2) Subsequent spreading may have taken place along Alpha Ridge. This ridge is formed of over-thickened oceanic-type crust, possibly analogous to a within-plate oceanic plateau or an Icelandic-type spreading ridge. Highly vesicular and altered clasts of (?) alkali basalt were dredged from the wall of the graben-like valley at the ridge's crest. Alpha Ridge is dated to pre-late Cretaceous, possibly to the Long Normal magnetic episode of the Cretaceous, $120-80$ myBP (Mudie \& Jackson 1985; Forsyth et al. 1986).

(3) Ocean-floor spreading on the still active Nansen-Gakkel Ridge possibly started in early Tertiary (?61 myBP) and split a continental sliver (Lomonosov Ridge) off the Barents Shelf (Pitman \& Talwani 1972).

Additional clues on the tectonic setting of Franz Josef Land during the Lower Cretaceous may possibly be gleaned by searching for comparable Mesozoic histories at other Arctic localities. 
Virtually identical strata and fossils are located in Kong Karls Land (fig. 1). Rhaetian(?) to Barremian(?) platform sediments are capped by two or more basalt flows which are thus dated to $<120$ myBP (Harland 1973).

On Svalbard, the age of all the tholeiitic mafic sills (and presumably the (?) comagmatic lavas) is probably late Volgian to Berriasian or early Valanginian (145-130 myBP), i.e. slightly older than the Kong Karls Land lavas (Harland 1973). Based on radiometric age determinations, Burov et al. (1976) pointed to two phases of magmatic activity corresponding to $145 \pm 5 \mathrm{myBP}$ and $105 \pm 5$ myBP. The enclosing, up to $3 \mathrm{~km}$ thick, Mesozoic strata accumulated under platform conditions with marine shales and continental sandstones, plant beds and coal seams. An unconformity locally separated the youngest Jurassic from the earliest Cretaceous. Available analyses, compiled by Tyrrell \& Sandford (1933), may not be reliable; they indicate higher $\mathrm{K}_{2} \mathrm{O}$ and $\mathrm{TiO}_{2}$ values than the Franz Josef Land tholeiites studied here.

In N. Greenland, the late Cretaceous alkalineperalkaline acid volcanics of the Kap Washington Group are thought to be related to nearby alkali doleritic dike swarms of essentially the same age. They are both manifestations of crustal tension and within-plate rift magmatism, possibly related to late spreading on the Alpha Ridge or early spreading on the Nansen-Gakkel Ridge (Soper et al. 1982). Jurassic and Lower Cretaceous basic magmatism has not been recorded from $\mathrm{N}$. Greenland.

In the Canadian Artic Islands, the Mesozoic strata of the Sverdrup Basin range in thickness from about $4 \mathrm{~km}$ in marginal areas to $8 \mathrm{~km}$ in the central part of the basin. Despite the greater thickness in the Sverdrup Basin, the similarity of sediment types, and the timings of marine inundation, uplift and magmatic activity appear broadly similar to the Svalbard area (Balkwill 1978; Balkwill \& Haimila 1978; Christie 1979). Mafic magmatism was a long-lived, regionally significant part of basin development. Mafic sills range in age from about $200-90 \mathrm{myBP}$, with the majority falling around $127 \pm 15$ myBP, i.e. an age distribution very similar to mafic intrusions on Franz Josef Land. The available analyses, however, indicate tholeiites with much higher $\mathrm{K}_{2} \mathrm{O}, \mathrm{TiO}_{2}, \mathrm{P}_{2} \mathrm{O}_{5}, \mathrm{Rb}$ and $\mathrm{Sr}$ than the Franz Josef
Land tholeiities studied here (Blackadar 1964; Ricketts et al. 1985; Trettin \& Parrish 1987). The tectonic setting and geochemistry suggest a within-plate magmatic event. Some of the younger (c. 90 myBP) activity may be related to formation of the Alpha Ridge. It may be possible, when detailed geochemical and age-dating studies become available, to link the magmatic activity of the Sverdrup Basin to the activity on Svalbard and to the older (pre-Cretaceous) sills of Franz Josef Land.

There are no lower Cretaceous basalts in the Soviet Western Arctic apart from those on Franz Josef Land (Nalivkin 1973). Mesozoic platform sediments and basic volcanism appear to be absent from $E$ and NE Siberia, and from N Alaska. Adequate data for the submarine Chukchi Plateau and the Lomonosov Ridge are not available.

This brief survey of Mesozoic events on the exposed margins of the Arctic Ocean basin has failed to locate basic magmatism comparable to the Lower Cretaceous initial rifting tholeiites on Franz Josef Land. Older analyses of tholeiites from comparable settings and ages on Kong Karls Land and Svalbard are intriguingly different from the analyses presented in this study, and modern petrologic studies of these localities are clearly required. A broader survey of basic magmatism on Franz Josef Land is also required, both to confirm the general significance of our six Lower Cretaceous samples and to appraise the geochemistry of the older sills and dikes.

Present-day ideas of the tectonic evolution of the Arctic Ocean basin suggest that Lower Cretaceous ocean-floor spreading with associated initial rifting volcanism may have taken place in the Canada Basin and that the eastern edge of this basin abutted against the Barents Shelf. The igneous activity reported here from Franz Josef Land represents the only magmatism, up to now, which could be reasonably assigned to the formation of the Canada Basin. No related igneous materials from within or immediately adjacent to the Canada Basin have so far been reported. Formation of the Alpha Ridge appears to be a younger event (mid-, to late-Cretaceous). Assuming that Alpha Ridge is a within-plate oceanic plateau (see above) would not lead us to expect initial rifting tholeiites in its vicinity. However, if Alpha Ridge is considered to be an Icelandictype spreading ridge, then, by analogy to the 
magmatic history of East Greenland (Upton et al. 1984; Larsen et al., in press), the presence of initial rifting tholeiites in its marginal, continental regions is geologically reasonable. However, difficulties over the timing of events may still remain.

The balance of evidence, meagre as it is, appears to relate the Franz Josef Land, Lower Cretaceous magmatism to initial rifting of the continental margin during the early stages of opening of the Canada Basin. Considerable work, however, is needed to confirm (a) the age, evolution and mechanics of formation of the Canada Basin and (b) its relatedness to magmatism on Franz Josef Land. If we accept those models which consider the Lomonosov Ridge to have split away from the northern edge of the Barents Shelf in Lower Tertiary time, then Mesozoic sediments and igneous rocks closely comparable to those on Franz Josef Land can be predicted on the Lomonosov Ridge.

\section{Acknowledgements}

We thank the staff of the chemical laboratory at the Geological Survey of Greenland for major element analyses, and R. Gwozdz, H. Kunzendorf and Birthe Møller for trace element analyses, and J. Rønsbo for excellent support in the microprobe work. A. Krasnov (Interdepartmental Geophysical Committee, Soviet Academy of Science, Moscow) and G.L. Johnson (Department of the Navy, Office of the Chief of Naval Research, Arlington) kindly responded to our literature requests. We are greatly indebted to Peter Dawes for valuable comments on an early manuscript. The X-ray fluorescence and microprobe laboratories of the Geological Central Institute, Copenhagen University, are funded by the Danish Natural Science Research Council (S.N.F.).

\section{Dansk sammendrag}

Seks prøver af tholeiitisk basalt fra Franz Josef Land, USSR, er unders $ø$ gt geokemisk ved analyse af sảvel bjergarter som mineralbestanddele. Undersøgelsen tyder på, at de tholeiitiske basalter er knyttet til begyndende riftdannelse, idet de karakteriseres af lave indhold af $\mathrm{Ti}$ og andre inkompatible grundstoffer. De formodes dannet ved opsmeltning af kappebjergarter forarmet på disse elementer. Basalterne blev dannet i Nedre Kridt under begyndende oceanbundspredning $i$ Det arktiske Ocean, sandsynligvis under åbningen af Det canadiske Bassin.

\section{References}

Balkwill, H. R. 1978: Evolution of Sverdrup Basin, Arctic Canada. Bull. Am. Ass. Petroleum Geol. 62, 1004-1028.
Balkwill, H. R. \& Haimila, N. E. 1978: K/Ar ages and significance of mafic rocks, Sabine Peninsula, Melville Island, District of Franklin. Paper geol. Surv. Can. 78-1C, 35-38.

Basaltic Volcanism Study Project. 1981: In: Basaltic Volcanism on Terrestrial Planets. Pergamon, New York, N.Y., pp. 30-123.

Beliayevsky, N. A. et al. 1968: Transcontinental crustal sections of the U.S.S.R. and adjacent areas. Can. J. Earth Sciences $5,1067-1078$.

Bisset, C. B. 1930: Geological notes on North-East Land (Spitzbergen) and Franz Josef Land. British Arctic Expedition of 1925. Trans. Edinburgh Geol. Soc. 12, 196-206.

Blackadar, R. G. 1964: Basic intrusions of the Queen Elizabeth Islands, District of Franklin. Bull. geol. Surv. Can. 97, 36 pp.

Brooks, C. K. 1973: Rifting and doming in southern East Greenland. Nature (Phys. Sci.). 244, 23-25.

Brooks, C. K. \& Jakobsson, S. P. 1974: Petrochemistry of the volcanic rocks of the North Atlantic ridge system. In: $\mathrm{L}$. Kristjansson (Editor), Geodynamics of Iceland and the North Atlantic area. Reidel, Dordrecht, pp. 139-154.

Brooks, C. K., Nielsen, T. F. D. \& Petersen, T. S. 1976: The Blosseville Coast basalts of East Greenland: Their occurrence, composition and temporal variations. Contrib. Mineral. Petrol. 58, 279-292.

Buddington, A. F. \& Lindsley, D. H. 1964: Iron-titanium oxide minerals and synthetic equivalents. J. Petrology, 5, 310 357.

Burke, K. \& Dewey, J. F. 1973: Plume-generated triple junctions: Key indicators in applying plate tectonics to old rocks. J. Geol. 81, 406-433.

Burov, J. P., Krasilscikov, A. A., Firsov, L. V. \& Klubov, B. A. 1976: The age of the Spitsbergen dolerites. Norsk Pola rinst. Árbog 1975, 101-108.

Christie, R. L. 1979: The Franklinian Geosyncline in the Canadian Arctic and its relationship to Svalbard. Skrifter NorskPolarinstitut 167, 263-314.

Churkin, M., Jr., Soleimani, G., Carter, C. \& Robinson, R. 1981: Geology of the Soviet Arctic; Kola Peninsula to Lena River. In: A.E.M. Nairn et al. (Editors), The Arctic Ocean in the collection The Ocean Basins and Margins, Vol. 5. Plenum Press, New York, pp. 331-357.

Deer, W. A., Howie, R. A. \& Zussman, J. 1978: Rock-forming Minerals. Vol. 2A. Single-Chain Silicates (2nd Edition). Longman, London.

Dibner, V. D. 1957: Geological structure of Franz Josef Land. Trans. NIIGA. 81, 11-20.

Dibner, V. D. 1970: Franz Josef Land and Victoria Island. In: B. V. Tkachenko \& B. Kh. Egiazarov (Editors), Geology of U.S.S.R. Vol. 26, Soviet Arctic Islands. Nedra, Moscow, pp. 60-102 (in Russian).

Dibner, V. D. \& Krylova, N. M. 1963: Stratigraphic position and material composition of coal measures in Franz Josef Land. Int. Geol. Rev. 7, 1030-1038. (Sovet. geol. 1963, no. 7, 77-89, in Russian).

Dibner, V. D., Razin, V. K. \& Ronkina, Z. Z. 1962: Lithology and conditions of formation of Mesozoic sediments of Franz Josef Land. Trans. Inst. Geol. Arktiki 126, 44-74 (in Russian).

Forsyth, D. A., Asudeh, I., Green, A. G. \& Jackson, H. R. 1986: Crustal structure of the northern Alpha Ridge beneath the Arctic Ocean. Nature 322, 349-352.

Gabrielsen, R. H., Færseth, R., Hamar, G. \& Rønnevik, H. 1984: Nomenclature of the main structural features of the Norwegian Continental Shelf north of the 62nd parallel. In: A.M. Spencer et al. (Editors), Petroleum Geology of the North European Margin. Norwegian Petroleum Society (Graham \& Trotman, London), pp. 41-60.

Gakkel, Ya. Ya., Dibner, V. D. \& Litvin, V. N. 1968: The main features of endogene geomorphology and tectonism 
of the Atlantic-Arctic province of the Arctic Ocean. Problemii Arktiki i Antarktiki 285, 28-36 (in Russian).

Grove, T. L. \& Baker, M. B. 1984: Phase equilibrium controls on the tholeiitic versus calc-alkaline differentiation trends. J. Geophys. Res. 89, 3253-3274.

Hald, N. \& Waagstein, R. 1984: Lithology and chemistry of a 2 $\mathrm{km}$ sequence of Lower Tertiary tholeiitic lavas drilled on Soduroy, Faeroe Islands (Lopra-1). In: O. Berthelsen et al. (Editors), The deep drilling project 1980-1981 in the Faeroe Islands. Ann. Soc. Sci. Færoensis, 15-38.

Harland, W. B. 1973: Mesozoic geology of Svalbard. In: M. G. Pitcher (Editor), Arctic Geology, Mem. AAPG 19, 135148.

Harland, W. B., Gaskell, B. A., Heafford, A. P., Lind, E. K. \& Perkins, P. J. 1984: Outline of Arctic post-Silurian continental displacements. In: A. M. Spencer et al. (Editors), Petroleum Geology of the North European Margin. Norwegian Petroleum Society (Graham \& Trotman, London), pp. 137-148.

Holm, P. E. 1985: The geochemical fingerprints of different tectonomagmatic enviroments using hygromagmatophile element abundances of tholeiitic basalts and basaltic andesites. Chem. Geol. 51, 303-323.

Holmes, A. 1918: The basaltic rocks of the Arctic region Mineral. Mag. 18, 180-223.

Horn, G. 1930: Franz Josef Land. Natural history, discovery, exploration, and hunting. Skrifter om Svalbard og Ishavet. $29.54 \mathrm{pp}$.

Hubbard, R. J., Edrich, S. P. \& Rattey, R. P. 1987: Geologic evolution and hydrocarbon habitat of the "Arctic Alaska Microplate". Marine and Petroleum Geology 4, 2-34.

Jackson, F. G. 1899: A Thousand Days in the Arctic. London and New York. Vol. I, II, 551 and $580 \mathrm{pp}$.

Koettlitz, R. 1898: Observations on the geology of Franz Josef Land. Geol. Soc. London, Quart. J. 54, 620-652.

Larsen, L. M., Watt, W. S. \& Watt, M. in press: Geology and petrology of the Lower Tertiary plateau basalts of the Scoresby Sund region, East Greenland. Bull. Grønlands geol. Unders.

Masuda, A., Nakamura, N. \& Tanaka, T. 1973: Fine structures of mutually normalised rare-earth patterns of chondrites. Geochim. Cosmochim. Acta 37, 239-248.

Mudie, P. J. \& Jackson, H. R. 1985: Summary/Sommaire. In: H. R. Jackson et al. (Editors), Initial Geological Report on CESAR the Canadian Expedition to Study the Alpha Ridge, Arctic Ocean. Paper geol. Surv. Can 84-22, 3-10.

Nalivkin, D. S. 1973: Geology of the U.S.S.R, Oliver \& Boyd, Edinburgh. 855 pp.

Neprochnov, Yu. P., Gol'mshtok, A. Ya. \& Yel'nikov, I. N. 1984: Geophysical investigations of the subsurface structure of the bottom of the Barents Sea (4th, 6th and 8th cruises of the R/V Professor Shtokman). Oceanology 24, 141-143.

Newton, E. T. \& Teall, J. J. H. 1897: Notes on a collection of rocks and fossils from Franz Josef Land made by the Jackson-Harmsworth Expedition during 1894-1896. Geol. Soc. London, Quart. J. 53, 477-519.

Newton, E. T. \& Teall, J. J. H. 1898: Additional notes on rocks and fossils from Franz Josef Land. Geol. Soc. London, Quart. J. 54, 646-652.

Pearce, T. H., Gorman, B. E. \& Birkett, T. C. 1975: The
$\mathrm{TiO}_{2}-\mathrm{K}_{2} \mathrm{O}-\mathrm{P}_{2} \mathrm{O}_{5}$ diagram; a method af discrimination between oceanic and non-oceanic basalts. Earth Planet. Sci. Lett. 24, 419-426.

Pitman, W. C. \& Talwani, M. 1972: Sea-floor spreading in the North Atlantic. Bull. geol. Soc. Am. 83, 619-646.

Ricketts, B., Osadetz, K.G. \& Embry, A.F. 1985: Volcanic style in the Strand Fiord Formation (Upper Cretaceous), Axel Heiberg Island, Canadian Arctic Archipelago. Polar Research 3 n.s., 107-122.

Soper, N. J., Dawes, P. R. \& Higgins, A. K. 1982: CretaceousTertiary magmatic and tectonic events in North Greenland and the history of adjacent ocean basins. Meddr. Grønland, Geosci. 8, 205-220.

Steel, R. J. \& Worsley, D. 1984: Svalbard's post-Caledonian strata - an atlas of sedimentational patterns and palaeogeographic evolution. In: A. M. Spencer et al. (Editors) Petroleum Geology of the North European Margin. Norwegian Petroleum Society (Graham \& Trotman, London), pp. 109-135.

Sørensen, I. 1975: X-ray fluorescence spectrometry at GGU. Rapp. Gronlands Geol. Unders. 75, 16-18.

Tailleur, I. L. 1973: Probable rift origin of Canada Basin, Arctic Ocean. In: M. G. Pitcher (Editor), Artic Geology, AAPG Mem. 19, 526-535.

Tarakhovskiy, A. N., Fishman, M. V., Shkola, I. V. \& Andreichev, V. L. 1982: Age of traprocks of Franz Josef Land. Doklady Acad. Nauk SSSR, Earth Science Section 267, 88-91.

Tarakhovskiy, A. N., Fishman, M. V., Shkola, I. V. \& Andreichev, V. L. 1983: Age of traps of Franz Josef Land. In: Prognostication and evaluation of nickel content of new ore regions in the north of the Siberian Platform. Sevmorgeologiya, Leningrad, 100-107, 145.

Trettin, H. P. \& Parrish, R. 1987: Late Cretaceous bimodal magmatism, northern Ellesmere Island: isotopic age and origin. Can. J. Earth Sci. 24, 257-265.

Tyrrell, G. W. \& Sandford K. S. 1933: Geology and petrology of the dolerites of Spitzbergen. Roy. Soc. Edinburgh Proc. 53: pt. 3, no. 21, 284-321.

Upton, B. G. J., Emeleus, C. H. \& Beckinsale, R. D. 1984: Petrology of the northern East Greenland Tertiary flood basalts: Evidence from Hold with Hope and Wollaston Foreland. J. Petrol. 25, 151-184.

Vlodavetz, V. I. 1934: On the petrography of Hooker Island. Trudy Arkticheskovo Instituta 13, 87-113 (in Russian, English summary).

Vogt, P. R. \& Ostenso, N. A. 1973: Reconnaissance geophysical studies in Barents and Kara Seas Summary. In: M. G. Pitcher (Editor), Arctic Geology, AAPG Mem. 19, 588598.

Waagstein, R. \& Hald, N. 1984: Structure and petrography of a $660 \mathrm{~m}$ lava sequence from the Vestmanna -1 drill hole, lower and middle basalt series, Faeroe Islands. In: $O$. Berthelsen et al. (Editors), The deep drilling project 19801981 in the Faeroe Islands. Ann. Soc. Sci. Færoensis, $39-70$.

Wood, D. A., Joron, J.-L., Treuil, M., Norry, M. \& Tarney, J. 1979: Elemental and $\mathrm{Sr}$ isotope variations in basic lavas from Iceland and the surrounding ocean floor. The nature of mantle source inhomogeneities. Contrib. Mineral. Petrol. 70, 319-339. 